\title{
WHY DON'T MIGRANTS WITH SECONDARY EDUCATION RETURN
}

\section{Renata Ivanova Byeongju Jeong}
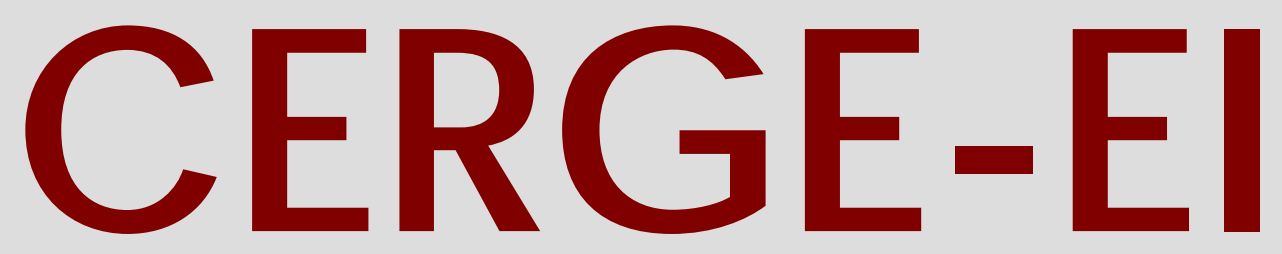

Charles University Centerfor Economic Research and Graduate Education Academy of Sciences of the Czech Republic Ec onomic s Institute 


\title{
Working Paper Series (ISSN 1211-3298)
}

\section{Why Don't Migrants with Secondary Education Return?}

\author{
Renata Ivanova \\ Byeongju Jeong
}

CERGE-EI

Prague, September 2011

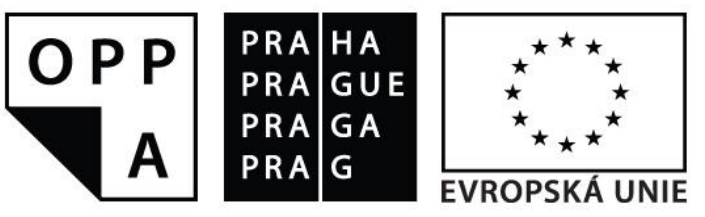

EVROPSKÝ SOCIÁLNÍ FOND

PRAHA \& EU: INVESTUJEME DO VAŠÍ BUDOUCNOSTI 
ISBN 978-80-7343-252-2 (Univerzita Karlova. Centrum pro ekonomický výzkum a doktorské studium)

ISBN 978-80-7344-244-6 (Národohospodářský ústav AV ČR, v.v.i.) 


\title{
Why Don't Migrants with Secondary Education Return?*
}

\author{
Renata Ivanova ${ }^{\dagger} \quad$ Byeongju Jeong ${ }^{\ddagger}$ \\ CERGE-EI CERGE-EI ${ }^{\S}$
}

November 2011

\begin{abstract}
The paper attempts to explain a U-shaped pattern of return migration rates with respect to educational attainment. We develop a two period OLG model with emigration and return migration decisions undertaken by agents heterogeneous in terms of educational attainment. The immigration policy is considered as an additional determinant for the migration decision. The model predicts that the combination of two forces - relative returns to schooling and uncertain opportunities for status adjustment - results in favorable conditions for migrants with secondary education to remain abroad permanently.
\end{abstract}

\begin{abstract}
Abstrakt
Tento článek se pokouší vysvětlit schěma ve tvaru U v míře návratu migrantů ve vztahu k dosaženému vzdělání. Vytváříme OLG model na dvě období, kde jsou rozhodnutí emigrovat a navrátit se udělána činiteli, kteří jsou heterogenní z pohledu dosaženého vzdělání. Imigrační politika je brána $\mathrm{v}$ potaz jako další determinanta migračního rozhodnutí. Model předpovídá, že kombinace dvou sil - relativní návratnost vzdělávání a nejisté příležitosti pro přizpůsobení statusu - vede ke kladným podmínkám k tomu, aby migranti se středoškolským vzděláním zůstali v zahraničí natrvalo.
\end{abstract}

Keywords: Return Migration, Skilled Migration, Returns to Education JEL Classification: F2, F22

*We are thankful to Evangelia Vourvachaki, Michal Kejak, Randy Filer, Alejandro Portes and Douglas S. Massey for helpful suggestions and comments. We are grateful to Robin-Eliece Mercury and Laura Strakova for English editing. All errors remaining in the text are the responsibility of the authors.

$\dagger$ Email: Renata.Ivanova@cerge-ei.cz

${ }^{\ddagger}$ Email: Byeongju.Jeong@cerge-ei.cz

$\S$ Center for Economic Research and Graduate Education - Economics Institute, a joint workplace of Charles University in Prague and the Academy of Sciences of the Czech Republic. Address: CERGE-EI, P.O. Box 882, Politických věžnů 7, Prague 1, 111 21, Czech Republic 


\section{Introduction}

The significant disparities in development that exist between countries motivate people to move to locations with better earning opportunities and higher standards of living. However, despite available employment and possibilities to accumulate savings and send remittances provided by the destination countries, a substantial number of migrants eventually return to their origins. Statistical evidence reveals that the re-emigration rates from the traditional destination countries are as high as $40 \%$ for the UK, $23 \%$ for Canada, and 19\% for the USA, with major re-emigration taking place within the first five years and significantly declining after that (Borjas \& Bratsberg, 1996; OECD, 2008; Dustmann \& Weiss, 2009) ${ }^{1}$.

In the past, return migration was associated with a failure or inability to assimilate in the destination, as emigration was perceived as resettlement on a permanent basis. However, contemporary trends in international labor mobility considerably challenge the traditional migration paradigm. Today, migration is characterized by the temporary nature of resettlement and return, on the contrary, serves as a measure of immigration success, as it takes place when the initial emigration objective, for instance, achievement of a savings target, is reached (Massey \& Sanchez, 2010).

A growing number of surveys conducted among the returned population in the source countries sheds light on the motivation behind the return decision of migrants. Among the dominant reasons for return migration prevail family and homesickness, followed by legal barriers imposed by the immigration policy, and failed expectations $^{2}$ (Massey \& Redstone, 2008; DoTM, 2010). As for the reasons for the initial emigration, the most frequently mentioned are the lack of employment opportunities in the origin countries together with substantial wage differentials that exist between developed destinations and developing source countries.

Migrants represent a non-random sample of the source country's population, being self-selected into emigration as well as into a subsequent return with respect to observable and unobservable characteristics (Borjas, 1987; Borjas \& Bratsberg,

\footnotetext{
${ }^{1}$ The terms "re-emigration rate" and "return rate" are used interchangeably throughout the paper. However, the re-emigrating population includes two categories: those who return to the country of origin and those who move to a third location. Partial justification for the synonymous usage of the two terms can be drawn from Nekby (2006) and Bratsberg, Raaum \& Sorlie (2007) who show, using data from Sweden and Norway, that a substantial share of the re-emigrating population is actually returning to the countries of origin rather than moving to a third location.

${ }^{2}$ Using data for seven source countries covered in the framework of the DoTM Project, we obtain the following ranking of reasons for return migration (average percentage of responses): family reasons - $30 \%$; legal barriers - $28 \%$; homesickness - $13 \%$; end of the contract - $12 \%$; failed expectations - $10 \%$, and etc.
} 
1996). One of the important and widely analyzed dimensions of selectivity is the educational attainment of migrants - an observable component of human capital which is used as a proxy for individual skills. The educational composition of migration flows has a direct impact on the economic development of the source countries (Beine, Docquier \& Rapoport, 2001; Docquier \& Marfouk, 2006). Substantial return migration flows create a potential channel of economic growth for the countries of migrants' origin (Dos Santor \& Postel-Vinay, 2003). Knowledge of educational selectivity and an understanding of the motivation guiding the return decision are also important for the improvement of the efficiency of the motivation schemes developed by the source countries intended to lure back their expatriates.

The available statistical evidence on the educational composition of migration flows reveals a number of peculiar patterns. In particular, the emigration rates, on average, increase with education (Feliciano, 2005; Grogger \& Hanson, 2011). A handful of countries represent the traditional suppliers of relatively low-skilled labor, among them Mexico, Morocco, and Turkey (Gould \& Moav, 2009). Such positive selectivity of migrants along the educational dimension can be partially explained by the quality-selective immigration policies adopted by major destination countries in the late 1980s in favor of advanced education and special skills (Docquier \& Marfouk, 2006; Papademetrious, Meissner \& Rosenblum, 2009).

The analysis of return migration dynamics is complicated by the lack of relevant data. The return flows are latent as the returning population, as a rule, does not undergo direct registration at the moment of re-entry. The data which do exist reveal that return rates tend to be highest among the least educated and migrants with an advanced education, and the lowest among migrants with only a secondary education. This U-shape pattern of return rates is observed both in the aggregate immigrant stock of the destination countries, as well as in the single source country stock of return migrants. In particular, according to the OECD International Migration Outlook 2008, the average re-emigration rates among men who entered the US at the age of 30 or older after five years of residence comprise: $34.4 \%$ for the low-educated, $4.4 \%$ for the middle-educated, and $23.5 \%$ for the highly-educated (Figure 1 in Appendix B). ${ }^{3}$

At the level of a single source country, return migration rates are also found to be U-shapes with respect to the educational attainment of returnees. As an

\footnotetext{
${ }^{3}$ We adopt the following classification of the population with respect to educational attainment: low-educated - less than secondary school; middle-educated - completed secondary school or an equivalent vocational training program; highly educated - college degree and higher (OECD, 2008).
} 
illustration, Figures 2a and 2b in Appendix B depict the return migration rates from such destinations as the US and Spain for a group of Latin American countries.

Recently collected data by the Institute of Public Policy Research, London in seven developing countries provide additional evidence on the educational selectivity of return migrants. For such countries as Jamaica, Ghana, Vietnam, and Macedonia, the return pattern was found to be U-shaped with respect to education (DoTM, 2010). The return migration ratios for these countries are summarized in Table 1 in Appendix C.

The U-shaped pattern of return migration rates observed in the data cannot be accounted for by the existing theoretical models of migrants' selectivity. The theory, on the contrary, predicts the pattern to be either an inverse U-shape (Borjas \& Bratsberg, 1996) or positively sloped (Mayr \& Peri, 2008). Our paper addresses this puzzle as we develop a theoretical framework which attempts to provide a rationale for the relatively low return rates among migrants with a secondary education. In particular, we build a two-period OLG model with heterogeneous agents in terms of educational attainment who make migration and return decisions during their life cycle. Our model is based on the migration decision mechanism proposed by Borjas \& Bratsberg (1996); however, it incorporates two additional determinants of migration decisions - immigration costs and immigration policy parameters.

The migration outcome based on the individual optimization problem is influenced by a set of economic and non-monetary factors. Besides the economic determinants of the individual migration decision, such as returns to schooling and the experience premium proposed by previous studies, we incorporate the effect of non-monetary factors which are modeled in the form of immigration costs. The latter reflect the costs of assimilation and the psychological costs of separation from family. The role of non-monetary, idiosyncratic factors in the return decision of migrants seems to be important, as signaled by the findings of recent surveys conducted among the returned population (DoTM, 2010; Massey \& Sanchez, 2010).

Another deviation of our framework from similar studies is in the consideration of the immigration policy impact which shapes the individual migration outcome. The evidence concerning the educational composition of migration and return migration flows presented above is based on census data which register the foreign born population regardless of the category of admission. Previous theoretical studies analyzed the migration behavior of those migrants who enter destination countries holding a permanent residence permit. It explains why the impact of immigration policy was not considered. However, our brief investigation of immigration policy, 
in particular the US immigration policy as the major destination country, indicates that immigration policy is restrictive at the stage of the initial emigration, but is even more selective at the stage of status adjustment into permanent residence. As the status adjustment is restricted on a skill basis, it should be incorporated into the analysis of the return migration decision undertaken by migrants with different educational attainments.

Predictions of the existing theoretical models concerning the educational composition of return migration flows are largely dependent on an assumption about the relative value of returns to schooling in the source and destination countries. We check the predictions of our model by considering actual values of the returns to schooling for the sample of source and destination countries. Our sample reveals that returns to schooling tend to be higher in the source countries, reflecting a relative scarcity of educated labor.

As an outcome, our model explains the variation of return migration rates across educational levels by the combination of two forces - incentives and opportunities - which create favorable conditions for migrants with, particularly, secondary education to remain abroad on a permanent basis. At the ends of the skills distribution, migrants with low educational attainment have incentives for permanent immigration but lack opportunities, while those with high educational attainment have opportunities to adjust their status but lack the incentives to do that.

The rest of the paper is organized as follows. In the next section, we provide a brief summary of the theoretical and empirical literature on educational selectivity of return migrants. Next, using a sample of sending and receiving countries, we draw conclusions about the actual patterns of variation of emigration and return migration rates across educational attainments and compare returns to schooling in the source and destination countries from our sample. In the modeling section, we develop a theoretical model with emigration and return migration decisions undertaken by heterogeneous agents in terms of education and consider its predictions under two regimes - free labor mobility and restricted immigration opportunities. In the last section we conclude.

\section{Literature Review}

In this paper, we consider the subgroup of migrants called economic migrants, those who emigrate for employment purposes in order to take a job offer abroad or to search for employment. The countries of migrants' origin, as a rule, are characterized by 
a rapidly growing labor force and slow economic growth, resulting in a shortage of employment opportunities (OECD, 2008; UNDR, 2009). Moreover, the wage differentials that exist between the source and destination countries are substantial, thus allowing migrants to accumulate savings and send remittances to the households left in the origin (DoTM, 2010).

However, the motivation guiding the return decision of migrants is more complex and poorly understood. The theoretical literature provides several explanations for return migration, and their comprehensive summary is presented in Yang (2006). Return takes place due to location specific preferences, achievement of a savings target, or due to the improvement of individual earning prospects in the home country realized in the form of an experience premium.

A number of recent surveys conducted in the source countries of the returned population provide evidence on the reasons behind emigration and return decisions. Examples of such surveys include the Latin American Migration Project and the New Immigrant Survey by the Center for Migration and Development at Princeton University and the Development on the Move Projects by the Institute of Public Policy Research, London. These surveys, despite different coverage of the source and destination countries and open-ended question format, yield similar findings concerning migrants' motivation and the ranking of motives. Among the reasons for the initial emigration, lack of employment opportunities in the origin country predominates, followed by the savings motive and desire to send remittances. As for the return migration decision, the primary motives for return revealed by all surveys are family reasons, such as homesickness or idiosyncratic family events, followed by policy constraints that create a barrier for the prolongation of the foreign stay on a legal basis, and to a lesser extent the achievement of a savings target, preference for the home country, and failed expectations (Massey \& Redstone, 2003; Massey \& Sanchez, 2010; DoTM, 2010).

Next, we analyze the findings concerning the difference in motivation among migrants with different educational levels. The seminal paper by Borjas (1987) represents a pioneering attempt to model the decision mechanism that explains the emigration behavior of educationally heterogeneous agents. The author introduces two types of selection - positive and negative - the realization of which is determined by the extent of income inequality in the home and destination countries. In the case of higher income inequality at the destination, the most skilled agents leave the home country to reap the benefits from higher returns to skills offered abroad. Thus, migrants are said to be positively self-selected with respect to education. On 
the contrary, when income inequality is larger at home, returns to skills are higher in the source country compared to the foreign country; thus, only agents from the lower tail of the skills distribution emigrate, while the most skilled remain at home (negative selection).

Return migrants comprise a sub-sample of the immigrant population; thus, the type of selection into the initial emigration affects the educational composition of the returning population. In their seminal paper, Borjas \& Bratsberg (1996) show that return migration intensifies the type of selection which guides the initial emigration. In particular, in the case of positive selection, the emigration of natives from the upper tail of the skills distribution, those who decide to return, are the least skilled migrants out of them. In the case of negative selection, the situation is reversed. Therefore, the selection mechanism proposed by Borjas \& Bratsberg (1996) predicts that regardless of the type of the initial selection, migrants with skills from the middle part of the distribution always return, while the ends of the skills distribution are always better off remaining abroad. For the aggregate stock of the immigrant population in the destination country, the model predicts intermediate (inverse Ushaped) selection into re-emigration. The authors tested their theoretical predictions using US data on permanent residence permit holders from the entry cohort of 19701985. Due to the lack of data on the educational attainment of migrants, the authors used the wage distribution to divide migrants into three educational groups.

Besides returns to schooling, the theoretical literature considers other determinants of emigration and return decisions that affect the educational composition of migration flows. Among them are the costs of resettlement and the experience premium (Borjas \& Bratsberg, 1996; Chiquiar \& Hanson, 2005; Mayr \& Peri, 2008). An individual migration decision is based on a comparison of wages paid in the destination country net of the resettlement costs with wages received at home. However, the immigration experience is thought to improve individual earnings in the home country, rewarding returnees for the additional human capital accumulated abroad in the process of on-the-job training. Therefore, the migration decision improves individual earnings in either case through permanent or temporary migration.

Predictions of the existing theoretical models concerning the educational composition of return migration flows are heavily dependent on the initial assumptions. For instance, the assumption of higher returns to schooling in the foreign country compared to that in the source country results in positive selection into emigration as well as in positive selection into the consequent return in the models by Borjas \& Bratsberg (1996) and Mayr \& Peri (2008). Other crucial assumptions concern the 
distribution of resettlement costs and the experience premium across educational attainments. In the next section, using a sample of the source countries for which the return migration rates were found to be U-shaped with respect to educational attainment, and a sample of the corresponding destination countries, we analyze available evidence on the actual size of the returns to schooling for different educational attainments. Our brief investigation reveals that returns to schooling tend to be higher in the source countries, and this finding will be used later in the paper when deriving the predictions of our theoretical model concerning return migration patterns.

The theoretical models described above consider the unidimensional structure of skills. A recent theoretical paper by Dustmann, Fadlon \& Weiss (2011) introduces a two-dimensional structure of skills, divided into home specific and foreign specific. The difference in the costs of skills accumulation and returns to various types of skills in the origin and destination countries result in a rich set of selection patterns with respect to the educational attainment of migrants. However, the major issue of such approach is the subjective nature of the criterion used to discriminate between the two types of skills. In the framework of our paper we adopt the unidimensional structure of individual skills.

The theoretical literature on the educational selectivity of return migration flows cannot account for the low return rates among the migrants with secondary education observed in the data. This implies that other determinants of the return decision exist which have not been accounted for. In the framework of our analysis, we will consider two additional determinants such as assimilation costs and immigration policy restrictions.

\section{Statistical Evidence}

The assumption about relative returns to schooling in the source and destination countries shapes to a large extent the predictions of the existing theoretical models concerning educational sorting of the immigrant and returning population. In particular, the returns to schooling are assumed to be higher in the developed destination countries. In order to judge to what extent this important assumption is realistic, in this section we analyze the evidence on the returns to schooling for a sample of source countries. Our sample includes eleven source countries for which the U-shaped return migration rates were found, and two corresponding destination countries such as the US and Spain. The composition of the sample is determined by 
the data availability. Our findings are summarized in Tables 1, 2, and 3 in Appendix $\mathrm{C}$ and will be used later when checking the predictions of our theoretical model.

Table 2 contains relative skills supply and relative returns to secondary and tertiary education. The left-hand side of Table 2 allows us to judge the educational composition of the labor force. In the case of source countries, it is characterized by a large share of agents with primary education and at the same time a very negligible share of the tertiary-educated. The educational composition of the population in the developed destination countries, for instance in the US, significantly differs, being characterized by a large share of people with completed secondary education, followed by a significant share of the tertiary-educated labor. The relative scarcity of educated labor observed in the origin countries is reflected in the high returns to schooling in these countries.

The returns to schooling presented in the right-hand side of Table 2 stand for the log wage differentials between workers with a secondary education and primary education $\left(S P_{1}\right)$, and between the tertiary-educated and secondary-educated $\left(S P_{2} / S P_{1}\right)$. The returns to secondary education are robustly higher in all source countries compared to that in the US and Spain. Moreover, returns to tertiary education are higher for the majority of source countries with a minor exception for Argentina and Mexico, where the skill premium for people with advanced education is smaller than in the US.

Despite higher returns to schooling, emigration rates in our sample of source countries increase with educational attainment. The emigration rates presented in Table 3 are calculated as shares of the emigrant population with a particular educational attainment in the resident population of the source country with the same educational attainment. They represent the measures of the extent of brain drain. Our sample reveals mostly a positive selection of emigrants. Countries like Ghana, Jamaica, and Fiji are tremendously affected by brain drain as the emigration rates among highly-skilled nationals account for as much as 60-80 \%. Predominantly positive selection into emigration is an anticipated result due to the highly discriminative nature of the immigration policies adopted by major destination countries in the last decade of the 20th century. Comparing the educational selectivity of emigrants across destinations, we observe that the selection pattern is positive for the case of the US, and more diverse in the case of Spain, which might be an indicator of a more restrictive US policy compared to the one in Spain.

As was shown in introduction, the source countries in our sample are characterized by a U-shaped return migration pattern with respect to educational attainment 
(see Table 1 in Appendix C). As for the relative magnitude of return migration rates at the ends of the skills distribution, it varies substantially across destinations. In the case of the US, the return rates among the low-educated are higher than among the highly-educated. This may be the outcome of the restrictive US immigration policy. In the case of Spain, the return rates among the highly-educated, on the contrary, are larger than that among the low-educated.

The selection patterns observed in the data hint at the importance of immigration policy in shaping the size and composition of the immigrant flows by restricting opportunities for certain groups to emigrate in the first place, and for those who manage to emigrate to remain in the destination permanently and on a legal basis. The existing theoretical models of migrants' selectivity by Borjas \& Bratsberg (1996) and Mayr \& Peri (2008) analyze the return migration behavior of migrants who move to the destination countries holding permanent residence permits, thus facing no legal barrier for permanent resettlement. However, the statistical evidence on the educational composition of return migration flows presented in the introduction is based on census data. This type of data does not allow us to discriminate between different admission categories, thus, providing evidence on the return behavior of migrants who enter the destination countries under temporary as well as semi-permanent and permanent visas. Therefore, immigration policy may be a potential determinant of the educational selectivity of migrants. Below, we analyze the restrictive role of immigration policy on the example of the US.

The immigration policies of destination countries are highly discriminative with respect to migrants' education and origin (Papademetrious, Meissner \& Rosenblum, 2009). At the stage of emigration, the policy limits the number of admission categories for which low-educated migrants qualify and imposes annual quotas on admission under these categories. The number of admission categories as well as the size of quotas increase with the educational attainment of migrants. As an illustration, Table 4 in Appendix $\mathrm{C}$ summarizes the US admission categories available for economic migrants from different educational groups. The table reveals that for migrants with low levels of education only the $\mathrm{H}-2$ admission category is available, which is intended exclusively for temporary stays and does not impose any educational requirement. Thus, agents with a secondary education also qualify for $\mathrm{H}-2$ visas. The annual admission limit for this category is set to 66,000 visas.

The emigration opportunities for the middle-skilled are extended by an additional option - Visa Diversification Program or the Green Card lottery - which grants 55,000 permanent residence permits annually. The lottery has two notable 
restrictions: educational requirement (at minimum a high school degree and two years of experience) and a restricted list of origin countries that are allowed to participate in the program.

A variety of admission categories are available for agents with a tertiary education. Besides the two options for the middle-skilled - H-2 visas and Visa Diversification Programs - the highly-educated qualify for H-1B and O-type admissions. The latter are subject to the strict educational requirement of at minimum a BA degree. The size of the annual admission quotas for the H-1B category is set to 85,000 visas.

Immigration policy also plays an important role in the second stage of the migration process, when those agents who managed to migrate in the previous period apply for permanent residence. The transition from non-immigrant temporary admission into permanent residence is known as status adjustment. The restrictions imposed by the immigration policy on the process of status adjustment put loweducated migrants in an even less favorable position compared to migrants from other educational groups than at the stage of the initial emigration. Table 4 also summarizes available options for acquiring permanent residence among different educational groups.

Temporary non-immigrant admissions do not include an option for direct status adjustment, with the exception of the $\mathrm{H}-1 \mathrm{~B}$ visa. One means for economic migrants to apply for status adjustment is under an employment-sponsorship petition. The size of annual admissions for this category is limited to 120,000 permits which are granted on the basis of educational attainment within four preference categories. Preference is given to applicants with an advanced degree and special abilities. Another possibility for acquiring permanent residence is through the Diversification program, which is available only for agent with a secondary education or higher. Therefore, US immigration policy limits the opportunities for permanent immigration for low-educated migrants on the basis of employment sponsorship. As a rule, low-educated migrants acquire permanent residence on the basis of family sponsorship, as close relatives of US citizens or legal immigrants, or by overstaying their temporary visas and switching to the group of illegal migrants (Massey \& Sanchez, 2010).

We incorporate the immigration policy parameters into our model. First, we make an assumption about free labor mobility and later relax this assumption by considering the effect of the policy at both stages of the migration process. We also use the patterns of relative returns to skills derived from the data to check the predictions of our theoretical model concerning the educational composition of 
return migration flows.

\section{The Model}

Our theoretical framework is based on the selection mechanism developed by Borjas and Bratsberg (1996). However, we introduce additional determinants of the migration and return decisions and incorporate the selection mechanism into a complete model, explicitly stating the production and population structure. We construct a two-country model: the home country (indexed H) is a small, open economy, and the foreign country (indexed F) is a large country. A single, non-storable consumption good is produced by competitive firms in each country and consumed by local residents.

\section{Technology}

Competitive firms in the home country employ the CRS production function with disaggregate labor inputs:

$$
Y^{H}=A^{H}\left(L_{0}^{H}\right)^{\alpha_{H}}\left(L_{1}^{H}\right)^{\beta_{H}}\left(L_{2}^{H}\right)^{\gamma_{H}},
$$

where $Y^{H}$ is output, $A^{H}$ is total factor productivity, $L_{0}^{H}, L_{1}^{H}$, and $L_{2}^{H}$ are inputs of low, middle, and highly educated labor respectively, $\alpha_{H}, \beta_{H}$, and $\gamma_{H}$ are shares of low, middle, and highly educated labor respectively in the total output. The disaggregation of labor inputs across the three educational groups is used on purpose in order to explicitly model the emigration and return migration decisions of agents from each group.

The foreign country employs a similar CRS production function:

$$
Y^{F}=A^{F}\left(L_{0}^{F}\right)^{\alpha_{F}}\left(L_{1}^{F}\right)^{\beta_{F}}\left(L_{2}^{F}\right)^{\gamma_{F}}
$$

The home country is assumed as developing, and the foreign country as developed. This assumption translates into the condition $A^{H}<A^{F}$, meaning that a part of the wage differential between countries is due to the difference in productivity levels.

Perfect competition and cost minimization of the firms imply that factor prices are set equal to their marginal products:

$$
W_{i}^{H}=M P_{L_{i}}
$$


where $i=\{0,1,2\}$. We assume a composite structure of wages which consist of a base wage and a skill premium paid for the additional education:

$$
W_{i}^{H}=\mu^{H} S P_{i}^{H},
$$

where $S P_{i}^{H}$ is a home country skill premium for the ith type of labor, defined as:

$$
S P_{i}^{H}=\frac{W_{i}^{H}}{W_{0}^{H}}
$$

The skill premium for low-educated labor is normalized to 1 both in home and foreign countries. The base wage represents compensation for work which requires a minimum level of education, thus paid to agents with primary education.

\section{Population}

The population in the home country is characterized by an overlapping generations structure. Every period, a new cohort of a fixed unit size and with a fixed educational structure is born. The educational structure of a new cohort is determined exogenously:

$$
z_{0}+z_{1}+z_{2}=1
$$

where $z_{0}, z_{1}, z_{2}$ are shares of the low, middle, and high educational groups respectively in the total size of a new cohort. In the current specification of the model, we do not consider the schooling decision of agents, though it has been shown in previous studies that emigration opportunities affect the educational decisions of the population in the source countries, known as the incentive hypothesis. At the moment, we consider a simplified framework abstracting from any educational dynamics.

Each agent lives two periods, young (indexed 1) and old (indexed 2), and faces a decision about emigration to a foreign country in the first period of life. No emigration is allowed in the second period. Consequently, the population of the home country in every period of time includes agents from two generations: young sedentary agents and old agents who are either return migrants or a sedentary population. We assume that each agent supplies one unit of labor. Thus, the composition of an effective labor force in the home country every period is equal to:

$$
L_{i}^{H}=L_{i}^{H_{1}}+L_{i}^{H_{2}}+E L_{i}^{F H_{2}}
$$


where $L_{i}^{H}$ is the size of the effective labor force with educational level $i ; L_{i}^{H_{1}}$ is the size of the young population with educational attainment $i ; L_{i}^{H_{2}}$ is the size of the old population with educational attainment $i$, which includes those agents who did not emigrate in the last period; $L_{i}^{F H_{2}}$ is the number of old agents with education $i$ who emigrated in the previous period but returned in the current period, where $i=\{0,1,2\}$. The experience premium E represents the augmentation of the labor endowment of return migrants in the process of on-the-job training undertaken while working in the foreign country.

\section{The individual optimization problem}

Our model is based on a set of assumptions. Free labor mobility implies that migration opportunities are not restricted by the immigration policy of destination countries. This assumption will be relaxed later. There are no costs of resettlement; however, living abroad is associated with immigration costs $(M)$. They include the costs of assimilation (learning the language, adjusting to a new culture) together with the psychological costs (i.e., separation from family) and are paid in both periods in the case of permanent immigration. The costs are randomly distributed among agents within each educational group, and their size is known at the beginning of the first period. The exponential functional form of the immigration costs is assumed, implying that in each educational group some agents have very negligible immigration costs (due to kin abroad, foreign language proficiency, or lack of family ties) meaning that they would always emigrate, while for other agents the costs go to infinity, and they never emigrate. This assumption is important to ensure the interior solution, so that emigration and return migration take place among agents from all three educational groups. Table 3 shows that emigration rates are substantial within all educational groups and is the case for all source countries in our sample.

Moreover, we assume that the distribution of immigration costs is the same in all educational groups; thus, it does not depend on educational attainment. One may argue that this assumption is rather unrealistic and the process of assimilation may be harder for particular educational groups. Our attempt to model the variation of immigration costs across educational attainment assuming their multiplicative form did not yield the realistic predictions concerning the patterns of educational selectivity observed in the data. ${ }^{4}$ As an alternative, we model the immigration costs

\footnotetext{
${ }^{4}$ The derivations for the specification with multiplicative immigration costs are presented in Section 8.1 in Appendix A.
} 
in additive form as a lump-sum amount in order to match the data regularities. The lump-sum immigration costs taken in "time-equivalent" terms, thus as a fraction of wage, place a heavier burden on the low-educated migrants with lower wages, and decline with an increase in education. The lump-sum representation of immigration costs can be justified, for instance, by the same degree of homesickness among migrants with different educational attainments, or the equal costs of maintaining contact with the origin country.

Upon return to the origin country, migrants obtain the experience premium E. The existence of an experience premium is justified by a number of empirical studies which found the premium to be as high as 20-30 \% (Co, Gang, \& Yun, 2000; Lacuesta, 2006; Reinhold \& Thom, 2009). The migration experience translates into higher individual earnings upon return to the origin country through several mechanisms. As the major destination countries are highly developed, by working abroad migrants are exposed to the advanced technologies and managerial approaches which increase their productivity and can be transferred into the context of the origin country upon return. The foreign work experience is highly valued by employers in the origin countries, in particular those countries which are undergoing the transition to a market economy. Promotion up the job ladder and high propensity of return migrants to engage in entrepreneurial activities upon return serve as alternative explanations for the existence of the experience premium(de Coulon \& Piracha, 2005; Epstein \& Radu, 2009; Barrett \& Goggin, 2010). Therefore, temporary migration allows agents to improve their earnings, which is otherwise impossible without educational upgrading.

At the beginning of the first period, agent $j$ learns his educational type $i$ which determines the amount of labor efficiency he supplies for one unit of time. The inter-temporal utility function of any agent with educational attainment $i$ looks like the following (discounting is ignored):

$$
U_{i}=W_{i}^{1}+W_{i}^{2}
$$

where $W_{i}^{1}, W_{i}^{2}$ are the wages in the first (young) and second (old) periods of life for agents with educational attainment $i$. Agents are assumed to be risk-neutral; thus, they are concerned only with the maximization of the expected life-time earnings. The individual optimization problem is formulated as the following:

$$
\max U_{i}=W_{i}^{1}+W_{i}^{2},
$$


s.t. the constraints that depend on the location choice:

\section{First period earnings}

- Agent $j$ with educational attainment $i$ lives in the home country:

$$
W_{i}^{H}=\mu^{H} S P_{i}^{H}
$$

- Agent $j$ with educational attainment $i$ lives in the foreign country:

$$
W_{i}^{F}-M_{i j}=\mu^{F} S P_{i}^{F}-M_{i j}
$$

where $M_{i j}$ is the value of the individual immigration costs of agent $j$ with educational attainment $i$. In the case of permanent immigration, in the second period of life agent $j$ earns the same wage as in the first period and continues to pay assimilation costs.

\section{Second period earnings}

- Agent $j$ with educational attainment $i$ returns to the home country:

$$
W_{i}^{F H}=W_{i}^{H} E=\mu^{H} S P_{i}^{H} E,
$$

for $i=\{0,1,2\}$. The experience premium $\mathrm{E}$ is modeled multiplicatively as exogenous and as a constant fraction of wage for all educational groups, following Borjas and Bratsberg (1996). However, the absolute amount of the experience premium increases with education.

The individual optimization problem is solved backwards. At the beginning of the second period, an individual who emigrated in the first period decides whether to remain in the foreign country or to return home and receive benefits in the form of an experience premium. The second period optimization problem yields the threshold value for the immigration costs $\bar{M}_{i}$ (permanent immigration). A marginal agent with this value of costs is indifferent between remaining abroad and returning home. All migrants with immigration costs lower than the threshold are better off remaining abroad. On the contrary, migrants with higher values of immigration costs than the threshold value are better off returning.

The individual migration decision in the first period is made based on the maximization of life time utility. The solution of the first period optimization problem yields the threshold value of immigration costs $\tilde{M}_{i}$ (initial emigration) at which 
agents are indifferent between emigrating and remaining at home. Thus, those agents with immigration costs lower than the threshold would always emigrate, while those with high costs would remain in the home country. A detailed derivation of the thresholds is presented in Section 8.2 in Appendix A. The immigration costs thresholds are translated into population shares in the following way:

$$
\begin{aligned}
& \bar{M}_{i}=a \bar{N}_{i}^{b}, \\
& \tilde{M}_{i}=a \tilde{N}_{i}^{b},
\end{aligned}
$$

where $a$ and $b$ are parameters of the immigration costs function, and $b>1$. Two thresholds $\bar{N}_{i}$ and $\tilde{N}_{i}$ partition the population within each educational group $i$ into three categories with respect to migration status: sedentary population, permanent immigrants, and temporary migrants (Figure 3 in Appendix B). Table 5 summarizes the population shares with respect to migration status within each educational group.

Table 5. Population thresholds

\begin{tabular}{|c|c|c|}
\hline Educational group & Permanent migrants $\left(\bar{N}_{i}\right)$ & Emigrants $\left(\tilde{N}_{i}\right)$ \\
\hline Low & {$\left[\frac{1}{a}\left(\frac{\mu^{F}}{\mu^{H}}-E\right) \mu^{H}\right]^{\frac{1}{b}}$} & {$\left[\frac{1}{a}\left(\frac{\mu^{F}}{\mu^{H}}-(2-E)\right) \mu^{H}\right]^{\frac{1}{b}}$} \\
\hline Middle & {$\left[\frac{1}{a}\left(\frac{\mu^{F} S P_{1}^{F}}{\mu^{H} S P_{1}^{H}}-E\right) \mu^{H} S P_{1}^{H}\right]^{\frac{1}{b}}$} & {$\left[\frac{1}{a}\left(\frac{\mu^{F} S P_{1}^{F}}{\mu^{H} S P_{1}^{H}}-(2-E)\right) \mu^{H} S P_{1}^{H}\right]^{\frac{1}{b}}$} \\
\hline High & {$\left[\frac{1}{a}\left(\frac{\mu^{F} S P_{2}^{F}}{\mu^{H} S P_{2}^{H}}-E\right) \mu^{H} S P_{2}^{H}\right]^{\frac{1}{b}}$} & {$\left[\frac{1}{a}\left(\frac{\mu^{F} S P_{2}^{F}}{\mu^{H} S P_{2}^{H}}-(2-E)\right) \mu^{H} S P_{2}^{H}\right]^{\frac{1}{b}}$} \\
\hline
\end{tabular}

Two more categories of the population are: the sedentary population or non-migrants $\left(1-\tilde{N}_{i}\right)$ and return migrants $\left(\tilde{N}_{i}-\bar{N}_{i}\right)$, for $i=\{0,1,2\}$.

The size of the effective labor force in the home country in each period can be re-written in the following way:

$$
L_{i}^{H}=L_{i}^{H_{1}}+L_{i}^{H_{2}}+E L_{i}^{F H_{2}}=\left(\left(1-\tilde{N}_{i}^{1}\right)+\left(1-\tilde{N}_{i}^{2}\right)+E\left(\tilde{N}_{i}^{2}-\bar{N}_{i}^{2}\right)\right) z_{i}
$$

Combining the supply and demand sides of the model, we obtain the equilibrium population shares $\bar{N}_{i}^{*}$ and $\tilde{N}_{i}^{*}$. As a result, we end up with a system of six equations and six unknowns presented in Appendix A. However, due to its non-linearity, the system does not yield an explicit analytical solution. 


\section{The definition of equilibrium}

Given prices $\left\{W_{0}^{F}, W_{1}^{F}, W_{2}^{F}, W_{0}^{H}, W_{1}^{H}, W_{2}^{H}, E\right\}$, the exogenous distribution of immigration costs $\mathrm{M}$ and the exogenous educational composition of a new cohort $\left(z_{0}, z_{1}, z_{2}\right)$, the equilibrium is a sequence $\left\{\tilde{N}_{0}^{*}, \tilde{N}_{1}^{*}, \tilde{N}_{2}^{*}, \bar{N}_{0}^{*}, \bar{N}_{1}^{*}, \bar{N}_{0}^{*}\right\}$ which partitions the population into three groups with respect to emigration status: permanent migrants, temporary migrants, and the sedentary population, such that no agent can be better off by changing his migration status, and the following holds:

1. $\left\{\tilde{N}_{0}^{*}, \tilde{N}_{1}^{*}, \tilde{N}_{2}^{*}, \bar{N}_{0}^{*}, \bar{N}_{1}^{*}, \bar{N}_{0}^{*}\right\}$ solves the individual optimization problem (9)-(12).

2. $\left\{W_{0}^{H}, W_{1}^{H}, W_{2}^{H}\right\}$ and $\left\{W_{0}^{F}, W_{1}^{F}, W_{2}^{F}\right\}$ solve the firm's optimization problem (3) in home and foreign countries respectively.

3. Input markets clear: $S P_{1}^{H}=\frac{\beta_{H} L_{0}^{H}}{\alpha_{H} L_{1}^{H}}$ and $S P_{2}^{H}=\frac{\gamma_{H} L_{0}^{H}}{\alpha_{H} L_{2}^{H}}$, where $L_{i}^{H} s$ are defined by equation (15), and the population thresholds $\bar{N}_{i}, \tilde{N}_{i}$ are from Table 5 , for $i=\{0,1,2\}$.

\section{The characterization of equilibrium}

Despite the fact that we are not able to derive analytically the equilibrium population shares, we still can judge the relative magnitudes of the return migration rates in different educational groups. The return rates are calculated as fractions of the returned population in the total number of emigrants:

$$
R R_{i}=\frac{\tilde{N}_{i}-\bar{N}_{i}}{\tilde{N}_{i}}=1-\frac{\bar{N}_{i}}{\tilde{N}_{i}}=1-\left[\frac{\frac{\mu^{F} S P_{i}^{F}}{\mu^{H} S P_{i}^{H}}-E}{\frac{\mu^{F} S P_{i}^{F}}{\mu^{H} S P_{i}^{H}}-(2-E)}\right]^{\frac{1}{b}}
$$

for $i=\{0,1,2\}$. Under the current formulation of the model, the return migration rates vary across educational attainments being the functions of relative return to schooling in the foreign and destination countries as well as of the skill-invariant experience premium and parameters of the immigration costs function.

In Section 3 we analyzed the relative returns to schooling using a sample of source and destination countries. We concluded that relative returns to schooling abroad and at home decline with an increase in education. This implies that returns to schooling are higher in the source countries for all educational levels. Thus, the data reveals $1>\frac{S P_{1}^{F}}{S P_{1}^{H}}>\frac{S P_{2}^{F}}{S P_{2}^{H}}$. The model with lump-sum immigration costs predicts positive selection into return migration. 
As for the educational sorting of emigrants, the emigration rates are the functions of relative returns to schooling in the foreign and destination countries and of the size of the skill premium in the home country. Other determinants of the emigration decision are skill-invariant. The model predicts positive selection into emigration; however, this result is not automatically satisfied. We derive the conditions that generate this result in Section 8.2 in Appendix A.

\section{Result 1. Predictions of the model}

Under the assumptions of:

- Free labor mobility

- The experience premium as an exogenous and education-invariant fraction of wage

- The "time-equivalent" immigration costs declining with an increase in educational attainment

- The relative returns to schooling abroad and at home smaller than 1 and declining with an increase in education

$$
\left(1>\frac{S P_{1}^{F}}{S P_{1}^{H}}>\frac{S P_{2}^{F}}{S P_{2}^{H}}\right)
$$

the model with lump-sum immigration costs yields positive selection into emigration and positive selection into return migration.

In the current specification of the model, the lump-sum immigration costs place a heavier burden on migrants with lower wages, as a lump-sum amount comprises a larger fraction of their wage and further declines with educational attainment. Consequently, a smaller fraction of low-educated agents would be able to afford any particular realization of the immigration costs compared to other educational groups with higher wages, resulting in smaller emigration rates in this group.

Higher returns to schooling in the home country and the absolute amount of the experience premium increasing with education result in a situation in which wages of highly-educated agents, after a temporary stay abroad, become competitive with the compensation received in the foreign country. This explains the high emigration and substantial return migration rates among the agents with advanced education. As for the low-educated, the absolute amount of the experience premium obtained upon return is much smaller compared to other educational levels, and only migrants with extremely high values of immigration costs would return. In general, conditional 
on emigration in the first period, the least-educated agents would be better off remaining abroad permanently where the income inequality is smaller, compared to the home country. The middle-educated agents hold an intermediate position. Thus, return migration rates are increasing with education as well as the initial emigration rates.

The current specification of the model yields realistic predictions concerning the selectivity pattern of the immigrant population. However, the U-shaped pattern of the return migration rates remains unexplained.

\section{The Role of Immigration Policy}

The model described in Section 4 is built on the assumption of free labor mobility. In this section, we relax this assumption and model the impact of the immigration policy of the destination country on the emigration and return decisions of agents. In particular, we consider two variations of the model with lump-sum immigration costs, introducing in turn two sources of uncertainty: uncertain emigration opportunities and uncertain opportunities for status adjustment. First, we consider the role of the policy at the initial stage of emigration. A limited number of admission categories and annual restrictions on the number of admissions (quotas or immigration caps) within each category result in an uncertain emigration outcome for those agents who made a decision to emigrate. Thus, as a first modification, we introduce the immigrants acceptance rate $p_{i}$ which is increasing with educational attainment $p_{2}>p_{1}>p_{0}$.

Second, as an alternative modification, we introduce immigration policy restrictions in the form of uncertain opportunities for status adjustment in the second period for those migrants who wish to remain abroad permanently. The employmentbased adjustment of status is subject to those preference categories which favor migrants with advanced education. We introduce the second-period uncertainty as the status adjustment rate $q_{i}$ which is increasing in educational attainment of migrants $q_{2}>q_{1}>q_{0}$.

\subsection{Uncertain Emigration Opportunities}

The uncertainty of the emigration outcome in the first period does not change the individual optimization problem. Agents decide to emigrate if the net income obtained abroad outweighs the income received at home. Only after the individual 
decision concerning emigration is made, is a system of admission quotas applied randomly to the pool of agents who made the decision to go abroad. The acceptance rates are known to agents at the beginning of the first period and they affect the number of agents who actually emigrate $\tilde{N}_{i}$. A detailed solution of the individual optimization problem is presented in Section 8.3 in Appendix A. The immigration costs thresholds, as the solutions of the first and second periods' individual optimization problem, are the same as for the model in Section 4 . The fact that $p_{i}$ does not affect the individual optimization problem implies that those agents who are better off migrating would always apply for admission regardless of the size of the acceptance rate.

As the acceptance rate affects the number of agents who actually emigrate, it also affects the number of permanent immigrants, as the latter represent a subsample of the emigrating population. Consequently, the impact of $p_{i}$ on the return migration rates cancels out:

$$
R R_{i}=\frac{p_{i} \tilde{N}_{i}-p_{i} \bar{N}_{i}}{p_{i} \tilde{N}_{i}}=1-\frac{\bar{N}_{i}}{\tilde{N}_{i}} .
$$

Therefore, uncertain emigration opportunities do not affect individual decisions to emigrate and return, as those migrants who are better of migrating would consider any $p_{i}$ and would always apply for a visa. Moreover, $p_{i}$ has no effect on the return migration rates, and therefore does not allow us to improve the predictive power of our model.

\subsection{Uncertain Opportunities for Status Adjustment}

Next, we consider the impact of the immigration policy in the second period. We introduce a status adjustment rate $q_{i}$ which is highly dependent on the educational attainment of migrants: $q_{2}>q_{1}>q_{0}$. The rate is known for agents at the beginning of the first period.

A solution for the individual optimization problem is presented in Section 8.3 in Appendix A. Below, we summarize the major findings. The status adjustment rate $q_{i}$ does not affect the individual decision in the second period concerning permanent immigration. This implies that an individual decides on permanent immigration vs. return migration based solely on economic reasoning, and applies for status adjustment at any value of $q_{i}$. However, the status adjustment quota limits the actual number of migrants who are allowed to remain abroad permanently. It is randomly applied to the pool of all migrants who have intentions to become permanent immi- 
grants and to apply for status adjustment.

The first period optimization problem of agents who prefer temporary migration is not affected by the uncertain opportunities for status adjustment in the second period as they intend to return from the beginning. However, for these agents the immigration costs are so low that they are better off emigrating in the first period regardless of the uncertainty of status adjustment in the second period. Their expected earnings would be higher from emigration even if they fail to be accepted into permanent immigration compared to the earnings they would receive when staying in the home country. Thus, agents with low values of immigration costs would always emigrate in the first period. Consequently, the size of the emigrant population remains unchanged $\tilde{N}_{i}$.

As the policy affects only the number of permanent immigrants, this effect is reflected in the return migration rates:

$$
R R_{i}=1-\frac{q_{i} \bar{N}_{i}}{\tilde{N}_{i}}=1-\left[\frac{\frac{\mu^{F} S P_{i}^{F}}{\mu^{H} S P_{i}^{H}}-E}{\frac{\mu^{F} S P_{i}^{F}}{\mu^{H} S P_{i}^{H}}-(2-E)}\right]^{\frac{1}{b}} \cdot q_{i}
$$

for $i=\{0,1,2\}$. In the current specification of the model, the return migration rates are the functions of relative returns to schooling and status adjustment rates. Both variables are negatively related to return rates: $\frac{\partial R R_{i}}{\partial \frac{S P_{i}^{F}}{S P_{i}^{H}}}<0$ and $\frac{\partial R R_{i}}{\partial q_{i}}<0$ (see Appendix A, Section 8.3). However, relative returns to schooling and the status adjustment rate move in opposite directions with an increase in education. In particular, the status adjustment rate increases with educational attainment $q_{2}>q_{1}>q_{0}$, but relative returns to schooling decline $1>\frac{S P_{1}^{F}}{S P_{1}^{H}}>\frac{S P_{2}^{F}}{S P_{2}^{H}}$. As an outcome, the return migration rates may vary across educational groups in a number of ways. As a next step, we derive the conditions on the values of the relative skill premium and $q_{i} \mathrm{~s}$ that would allow the model to yield a U-shaped pattern of return migration rates along the educational dimension.

Our task is to show that $\exists$ pairs $\left\{\left(\frac{S P_{0}^{F}}{S P_{0}^{H}}, \frac{S P_{1}^{F}}{S P_{1}^{H}} ; \frac{S P_{2}^{F}}{S P_{2}^{H}}\right),\left(q_{0}, q_{1}, q_{2}\right)\right\}$, such that $R R_{0}>$ $R R_{1} \& R R_{2}>R R_{0}$ for given values of parameters $\mathrm{E}$ and $\frac{\mu^{F}}{\mu^{H}}$. We proceed by the following pair-wise comparison of return rates:

$$
\begin{aligned}
& \frac{S P_{0}^{F}}{S P_{0}^{H}}>\frac{S P_{1}^{F}}{S P_{1}^{H}} \& q_{0}<q_{1} \Rightarrow R R_{0}>R R_{1}, \\
& \frac{S P_{1}^{F}}{S P_{1}^{H}}>\frac{S P_{2}^{F}}{S P_{2}^{H}} \& q_{1}<q_{2} \Rightarrow R R_{2}>R R_{1} .
\end{aligned}
$$


Detailed derivations of these conditions are presented in Section 8.3 in Appendix A. We end up with the following set of conditions:

$$
\begin{gathered}
\frac{S P_{0}^{F}}{S P_{0}^{H}}=1, \\
\frac{S P_{1}^{F}}{S P_{1}^{H}} \in\left(\frac{E}{\mu^{F} / \mu^{H}}, 1-\frac{2(E-1)}{\mu^{F} / \mu^{H}}\right), \\
\frac{E}{\mu^{F} / \mu^{H}}<\frac{S P_{2}^{F}}{S P_{2}^{H}}<\frac{S P_{1}^{F}}{S P_{1}^{H}}, \\
\frac{q_{0}}{q_{1}}<\left(1-\frac{2(E-1)}{\frac{\mu^{F} S P_{1}^{F}}{\mu^{H} S P_{1}^{H}}-(2-E)}\right)^{\frac{1}{b}} \cdot\left(1+\frac{2(E-1)}{\frac{\mu^{F}}{\mu^{H}}-E}\right)^{\frac{1}{b}}, \\
\frac{q_{1}}{q_{2}}>\left(1-\frac{2(E-1)}{\frac{\mu^{F} S P_{2}^{F}}{\mu^{H} S P_{2}^{H}}-(2-E)}\right)^{\frac{1}{b}} \cdot\left(1+\frac{2(E-1)}{\frac{\mu^{F} S P_{1}^{F}}{\mu^{H} S P_{1}^{H}}-E}\right)^{\frac{1}{b}},
\end{gathered}
$$

where

$$
q_{1} \neq 0, q_{2} \neq 0, E \in(1,2), b>1, \frac{\mu^{F}}{\mu^{H}}>1
$$

Under conditions (18)-(22), the return migration rates follow a U-shaped pattern with respect to educational attainment $i: R R_{0}>R R_{1} \& R R_{2}>R R_{0}$.

Educational selectivity of return migration

We are not able to derive the restrictions for the individual values of status adjustment rates $q_{i}$, but only for their ratios $\frac{q_{0}}{q_{1}}$ and $\frac{q_{1}}{q_{2}}$. Different combinations of values for these two ratios result in different selectivity patterns among return migrants. Figure 4 depicts all possible combinations of values for the ratios and, consequently, all possible selection patterns for the values of the relative skill premium restricted by (18)-(20).

The threshold values of ratios obtained from (21)-(22) divide the ratio space into four regions as depicted in Figure 4. The return migration rates follow a Ushape in the region where, in relative terms, the ratios $\frac{q_{0}}{q_{1}}$ and $\frac{q_{1}}{q_{2}}$ significantly differ in magnitude. In particular, this is the region where the status adjustment rate of migrants with secondary education is close enough to the rate for the highly-educated migrants, and at the same time significantly larger than the status adjustment rate for the low-educated migrants. 
In the current specification of the model, the emigration rates are not affected by the size of the status adjustment rate. Therefore, the model's predictions concerning the selection into emigration remain as the one in Section 4. The model predicts positive selection into emigration and specifies the restrictions for the values of the relative skill premium and ratios of status adjustment rates that allow us to generate a U-shaped pattern of return migration with respect to educational attainment.

\section{Result 2. Predictions of the model}

Under the assumptions of:

- The experience premium as an exogenous and education invariant fraction of wage

- The "time-equivalent" immigration costs declining with an increase in education

- Relative returns to schooling smaller than 1 and declining with education $1>\frac{S P_{1}^{F}}{S P_{1}^{H}}>\frac{S P_{2}^{F}}{S P_{2}^{H}}$

- The status adjustment rate increasing with educational attainment $q_{2}>q_{1}>$ $q_{0}$,

the model yields positive selection into emigration and $U$-shaped return migration rates, when the status adjustment rate of the middle-educated is close enough to the rate of the highly-educated and significantly larger than the status adjustment rate of the low-educated migrants. this implies that the immigration policy of the destination country is especially restrictive toward low-educated migrants, and these restrictions are relaxed for higher levels of educational attainment.

\section{Explaining the U-shape}

The final specification of the model presented in Section 5.2 reveals two forces whose combination may result in a U-shaped variation of return migration rates across educational attainments. These are relative returns to schooling abroad and at home and the status adjustment rate to the permanent residence in the second stage of the migration process. Returns to schooling can be viewed as incentives to remain in the location where they are the highest. The status adjustment rate can be interpreted as an opportunity to remain in the foreign country legally and on a permanent basis. 
Low-educated agents have the strongest incentives to migrate and remain abroad permanently. The ratio of foreign and home wages is equal to the ratio of base wages for this educational group and is the largest compared to other educational attainments. The size of the base wage in the destination country is several times larger than that in the origin, reflecting a higher standard of living (Ashenfelter \& Jurajda, 2009). Low-educated agents who manage to emigrate in the first period have incentives to remain permanently, as the experience premium offered upon return represents a smaller improvement of wages compared to the net gains from immigration. Only those migrants with a high value of immigration costs would return. The opportunities for status adjustment are restricted by the skill-selective immigration policies of the destination countries. The temporary nature of occupations for which low-educated migrants qualify, for example construction or agriculture, does not allow them to apply for status adjustment under the employment sponsorship petition, which requires a long-term employment contract. Consequently, the low-educated migrants, in order to remain abroad, either adjust their status through family sponsorship, as the nearest relatives of US citizens or legal immigrants, or remain illegally by overstaying their temporary admissions. Those migrants who do not have relatives in the destination country and do not want to remain there illegally engage in a "yo-yo" migration pattern, reaping the benefits from temporary but repeated migration incidents (OECD, 2008). Therefore, low-educated migrants have incentives to remain abroad, yet their opportunities for permanent immigration are heavily restricted by the immigration policy, resulting in sizable return rates among them.

The motivation guiding migration behavior is different for the highly-educated migrants. Sizable emigration rates in this group are explained by the relative "inexpensiveness" of immigration, as higher wages paid at this educational level make the immigration costs easily affordable. However, the returns to schooling in the home country are higher than in the foreign country. This, together with the larger absolute value of the experience premium in this educational group obtained in the case of return, result in the improvement of earnings in the home country, making them competitive to the earnings abroad. Moreover, a high skill premium in the home country signals the value of an advanced education and consequently a higher status of the educated agents at home. On the contrary, the evidence shows that highly-educated migrants face strong discrimination and prejudice in the destination countries (Massey \& Sanchez, 2010). Therefore, this educational group does not have incentives to remain abroad permanently. However, migrants with an advanced 
education have opportunities for permanent immigration as they are welcomed by the destination countries.

The motivation guiding migration behavior among middle-educated agents, those with only a high-school degree or vocational training, can be summarized as the following. In terms of the initial emigration, the middle-skilled agents hold an intermediate position compared to other educational groups. Higher wage levels relative to the low-educated allow the middle-educated agents to afford higher immigration costs, which results in their higher emigration rates. However, the middle-educated still cannot afford to pay as high immigration costs as the highly-educated. As an outcome, we observe a positive selection into emigration with respect to education.

At the second stage of the migration process, middle-educated migrants turn out to have more opportunities to remain abroad permanently than do low-educated migrants, and at the same time more incentives for permanent immigration compared to the highly-educated. The occupational specifics of jobs in this educational group are characterized by more permanent employment contracts compared to the temporary occupations of the low-educated, which allows the middle-educated migrants to apply for status adjustment on the basis of employment sponsorship and not only to rely on family sponsorship as in the case of the low-educated. Moreover, the improvement of wages upon return due to the experience premium is not as high as for the highly-educated returnees and less than the wage gain from immigration. Therefore, compared to other educational groups, migrants with a middle level of education possess both the incentives and the opportunities for permanent immigration. As an outcome, the highest naturalization rates are observed in particular among migrants with only a secondary education compared to other educational groups (Massey \& Sanchez, 2010).

\section{Conclusion}

This paper presents a theoretical analysis of the educational selectivity of return migration and attempts to explain the U-shaped return migration rates observed in the data. We develop an OLG model and introduce additional determinants of the migration decision. The U-shaped pattern results from the combination of two forces - higher and increasing returns to schooling with educational attainment in the home country compared to the destination (incentives), and uncertain opportunities for status adjustment to permanent residence. Low-educated migrants have the strongest incentives to emigrate and remain abroad permanently, but they lack 
opportunities to remain abroad on a legal basis. Highly-educated migrants have opportunities, but they lack the incentives. The combination of the two forces in the case of migrants with secondary education results in both incentives and opportunities available in this group for permanent immigration on a legal basis.

As a possible modification of the model can be considered the experience premium variation across educational attainments. Empirical assessment of the experience premium among Irish return migrants undertaken by Barrett \& Goggin (2009) reveals a U-shaped pattern of the experience premium with respect to three educational groups. This implies that variation of the experience premium across educational attainments may potentially contribute to the explanation for the Ushaped return migration rates. However, the difference in the experience premium among different educational groups remains under-researched and thus poorly understood.

\section{References}

Ballard, R. (2005). Remittances and economic development in India and Pakistan. In S.M. Maimbo \& D. Ratha (Eds.), Remittances: Development Impact and Future Prospects (pp. 120-153). New York: World Bank.

Barrett, A., \& Goggin, J. (2010). Returning to the question of a wage premium for returning migrants (IZA Discussion Paper No. 4736). Bonn, Germany: The Institute for the Study of Labor.

Beine, M., Docquier, F., \& Rapoport, H. (2001). Brain drain and economic growth: Theory and evidence. Journal of Development Economics, 64, 275-289.

Belot, M., \& Hatton, T. (2008). Immigrant selection in the OECD (CEPR Discussion Paper No. 6678). London, UK: Center for Economic Policy Research.

Borjas, G., \& Bratsberg, B. (1996). Who leaves? The outmigration of the foreign-born. The Review of Economics and Statistics, 78(1), 165-176.

Borjas, G. (1987). Self-selection and earnings of immigrants. American Economic Review, 77, 531-553.

Bratsberg, B., Raaum, O., \& Sorlie, K. (2007). Foreign-born migration to and from Norway. In C. Ozden \& M. Schiff (Eds.), International Migration, Economic Development and Policy (pp.259-291). The World Bank.

Chiquiar, D., \& Hanson, G.H. (2005). International migration, self-selection, and the distribution of wages - evidence from Mexico and the United States. Journal of 
Political Economy, 113 (2), 239-281.

Co, C., Gang, I.N., \& Yun, M. (2000). Returns to returning. Journal of Population Economics, 13, 57-79.

Coulon, A. de, \& Piracha, M. (2005). Self-selection and the performance of return migrants: The source country perspective. Journal of Population Economics, 18, 779-807.

Development on the move: Measuring and optimizing migrants' economic and social impacts. IPPR, 2010.

The US Department of Homeland Security. Various years of the Immigration Statistics Yearbook. Washington, DC.

Docquier, F., \& Marfouk, A. (2006). International migration by educational attainment, 1990-2000. In C. Ozden \& M. Schiff (Eds.), International Migration, Remittances, and the Brain Drain (pp.151-199). The World Bank.

Docquier, F., \& Rapoport, H. (2007). Skilled migration: the perspective of developing countries (CReAM Discussion Paper Series 0710). University College London: Centre for Research and Analysis of Migration (CReAM).

Dos Santos, M.D., \& Postel-Vinay, F. (2003). Migration as a source of growth: the perspective of a developing country. Journal of Population Economics, 16 (1), 161.

Dustmann, C., Fadlon, I., \& Weiss, Y. (2011). Return migration, human capital accumulation and the brain drain. Journal of Development Economics, 95 (1), 58-67.

Epstein, G., \& Radu, D. (2007). Returns to return migration and determinants of subsequent moves. In EALE conference paper, EALE conference, 20-22 September 2007, Oslo.

Feliciano, C. (2005). Educational selectivity in US immigration: How do migrants compare to those left behind? Demography, 42(1), 131-152.

Goldin, C., \& Katz, L. (2007). Long-run changes in the US wage structure: Narrowing, widening, polarizing (NBER Working Paper 13568). Cambridge, MA: The National Bureau of Economic Research.

Gould, E., \& Moav, O. (2009). When "too much" inequality is not enough? The selection of Israeli emigrants (CEPR Discussion Paper 6955). London, UK: Center for Economic Policy Research.

Grogger, J., \& Hanson, H.G. (2011). Income maximization, and the selection, and sorting of international migrants. Journal of Development Economics, 95, 42-57.

Khadria, B.(2004). Migration of highly skilled Indians: Case studies of IT and health professionals (OECD: Science, Technology, and Industry Working Papers 
2004/06). Paris: OECD Editions.

Lucas, E.B., \& Chappell, L.(2009). Measuring migrations' development impacts: Preliminary evidence from Jamaica. London: Institute of Public Policy Research. Retrieved November 12, 2009, from www.ippr.org.

Manacorda, M., Sanchez-Paramo, C., \& Schady, N. (2005). Changes in returns to education in Latin America: The role of demand and supply of skills (CEP Discussion Paper 712). London, UK: London School of Economics.

Massey, D. \& Sanchez, M. (2010). Brokered Boundaries. New York: Russell Sage Foundation.

Mayr, K., \& Peri, G. (2008). Return Migration as a Channel of Brain Gain. (Discussion Paper 04/2008). London, UK: Center for Research and Analysis of Migration.

Nekby, L. (2006). The emigration of immigrants, return vs. onward migration: Evidence from Sweden. Journal of Population Economics, 19(2), 197-226.

OECD (2008). International Migration Outlook 2008. Paris: OECD Editions.

Papademetrious, D., Meissner, D., \& Rosenblum, M. (2009). Aligning Temporary Immigration Visas with US Labor Market Needs. (Working paper 07/2009). Washington, DC: Migration Policy Institute.

UNDP(2010), Human Development Report 2009: Human Mobility and Development. New York: United Nations.

Vertovec, S. (2007). Circular migration: The way forward in global policy? (Working Paper 04/2007). Oxford, UK: International Migration Institute.

World Bank (2006), Meeting the challenges of secondary education in Latin America and East Asia. Improving efficiency and resource mobilization. Washington, DC: World Bank.

Yang, D. (2006). Why do migrants return to poor countries? From Philippine migrants' responses to exchange rate shocks. (NBER Working Paper 12396). Cambridge, MA: The National Bureau of Economic Research. 


\section{Appendix A}

\subsection{Multiplicative Immigration Costs}

The individual optimization problem is formulated as the following:

$$
\max U_{i}=W_{i}^{1}+W_{i}^{2}
$$

s.t. the constraints that depend on the location choice:

\section{First period earnings}

- Agent $j$ with educational attainment $i$ lives in the home country:

$$
W_{i}^{H}=\mu^{H} S P_{i}^{H}
$$

- Agent $j$ with educational attainment $i$ lives in the foreign country:

$$
\frac{W_{i}^{F}}{M_{i j}}=\frac{\mu^{F} S P_{i}^{F}}{M_{i j}}
$$

\section{Second period earnings}

- Agent $j$ with educational attainment $i$ returns to the home country:

$$
W_{i}^{F H}=\mu^{H} S P_{i}^{H} E
$$

The individual optimization problem is solved backwards.

Second period: Return migration vs. Permanent immigration

Return migration takes place when

$$
\frac{W_{i}^{F}}{M_{i j}} \leq W_{i}^{H} E \Rightarrow M_{i j} \geq \frac{W_{i}^{F}}{W_{i}^{H} E}
$$

The threshold value of the immigration costs: $\bar{M}_{i}=\frac{W_{i}^{F}}{W_{i}^{H} E}$.

First period: Initial emigration decision

Agent $j$ with educational attainment $i$ will emigrate in the first period of life when

$$
\frac{W_{i}^{F}}{M_{i j}}+W_{i}^{H} E>2 W_{i}^{H} \Rightarrow M_{i j}<\frac{W_{i}^{F}}{(2-E) W_{i}^{H}}
$$

The threshold value of the immigration costs is: $\tilde{M}_{i}=\frac{W_{i}^{F}}{(2-E) W_{i}^{H}}$, where $E \in(1,2)$. 
The immigration costs thresholds partition the population in each educational group $i$ with respect to migration status. The thresholds are translated into the population shares in the following manner:

- Low-educated migrants

$$
\begin{gathered}
\bar{M}_{0}=\frac{\mu^{F}}{E \mu^{H}} \Rightarrow \bar{N}_{0}=\left[\frac{\mu^{F}}{a E \mu^{H}}\right]^{\frac{1}{b}}, \\
\tilde{M}_{0}=\frac{\mu^{F}}{(2-E) \mu^{H}} \Rightarrow \tilde{N}_{0}=\left[\frac{\mu^{F}}{a(2-E) \mu^{H}}\right]^{\frac{1}{b}} .
\end{gathered}
$$

- Middle-educated migrants

$$
\begin{gathered}
\bar{M}_{1}=\frac{\mu^{F} S P_{1}^{F}}{E \mu^{H} S P_{1}^{H}} \Rightarrow \bar{N}_{1}=\left[\frac{\mu^{F} S P_{1}^{F}}{a E \mu^{H} S P_{1}^{H}}\right]^{\frac{1}{b}}, \\
\tilde{M}_{1}=\frac{\mu^{F} S P_{1}^{F}}{(2-E) \mu^{H} S P_{1}^{H}} \Rightarrow \tilde{N}_{1}=\left[\frac{\mu^{F} S P_{1}^{F}}{a(2-E) \mu^{H} S P_{1}^{H}}\right]^{\frac{1}{b}} .
\end{gathered}
$$

\section{- Highly-educated migrants}

$$
\begin{gathered}
\bar{M}_{2}=\frac{\mu^{F} S P_{2}^{F}}{E \mu^{H} S P_{2}^{H}} \Rightarrow \bar{N}_{2}=\left[\frac{\mu^{F} S P_{2}^{F}}{a E \mu^{H} S P_{2}^{H}}\right]^{\frac{1}{b}}, \\
\tilde{M}_{2}=\frac{\mu^{F} S P_{2}^{F}}{(2-E) \mu^{H} S P_{2}^{H}} \Rightarrow \tilde{N}_{2}=\left[\frac{\mu^{F} S P_{2}^{F}}{a(2-E) \mu^{H} S P_{2}^{H}}\right]^{\frac{1}{b}} .
\end{gathered}
$$

The equilibrium shares of the population with respect to migration status are obtained from combining the demand (firms' optimization problem) and supply (individual optimization problem) sides of the labor market.

\section{Demand side: Returns to schooling}

$$
\begin{gathered}
S P_{1}^{H}=\frac{W_{1}^{H}}{W_{0}^{H}}=\frac{\beta_{H} L_{0}^{H}}{\alpha_{H} L_{1}^{H}}, \text { and } \\
S P_{2}^{H}=\frac{W_{2}^{H}}{W_{0}^{H}}=\frac{\gamma_{H} L_{0}^{H}}{\alpha_{H} L_{2}^{H}} .
\end{gathered}
$$

Re-writing the home country base wage and skill premia in terms of population 
shares, we obtain the following expressions:

$$
\begin{gathered}
\mu_{H}=\alpha_{H} A^{H}\left(\left[2\left(1-\tilde{N}_{0}\right)+E\left(\tilde{N}_{0}-\bar{N}_{0}\right)\right] z_{0}\right)^{\alpha-1}\left(\left[2\left(1-\tilde{N}_{1}\right)+E\left(\tilde{N}_{1}-\bar{N}_{1}\right)\right] z_{1}\right)^{\beta}\left(\left[2\left(1-\tilde{N}_{2}\right)+E\left(\tilde{N}_{2}-\bar{N}_{2}\right)\right] z_{2}\right)^{\gamma} \\
S P_{1}^{H}=\frac{\beta_{H}\left[2\left(1-\tilde{N}_{0}\right)+E\left(\tilde{N}_{0}-\bar{N}_{0}\right)\right] z_{0}}{\alpha_{H}\left[2\left(1-\tilde{N}_{1}\right)+E\left(\tilde{N}_{1}-\bar{N}_{1}\right)\right] z_{1}}, \text { and } \\
S P_{2}^{H}=\frac{\gamma_{H}\left[2\left(1-\tilde{N}_{0}\right)+E\left(\tilde{N}_{0}-\bar{N}_{0}\right)\right] z_{0}}{\alpha_{H}\left[2\left(1-\tilde{N}_{2}\right)+E\left(\tilde{N}_{2}-\bar{N}_{2}\right)\right] z_{2}}
\end{gathered}
$$

Substituting these expressions into equations (21)-(26), we end up with a system of six equations and six unknowns. The solution of the system is $\left\{\bar{N}_{0}^{*}, \tilde{N}_{0}^{*}, \bar{N}_{1}^{*}, \tilde{N}_{1}^{*}, \bar{N}_{2}^{*}, \tilde{N}_{2}^{*}\right\}$. However, due to the non-linearity of equations, the analytical solution cannot be derived explicitly.

\section{Return migration rates}

$$
R R_{i}=\frac{\tilde{N}_{i}-\bar{N}_{i}}{\tilde{N}_{i}}=1-\frac{\bar{N}_{i}}{\tilde{N}_{i}}=1-\left[\frac{2-E}{E}\right]^{\frac{1}{b}}
$$

The return migration rates defined by equation (36) are the functions of the experience premium $\mathrm{E}$ and the parameter $b$ of the immigration costs function, both being exogenous and constant across educational attainments by the initial assumptions. Therefore, under the current formulation, the model predicts equal return migration rates across educational groups or neutral selection into return.

As for the selection into emigration, the size of the emigrant population $\tilde{N}_{i}$ is a function of relative base wages and relative returns to schooling in the foreign and home countries, the experience premium, and the parameters $a$ and $b$ of the immigration costs functions. All these determinants except relative returns to schooling are education invariant. Thus, for the model to yield positive selection into emigration, the following conditions should be satisfied: $S P_{i}^{F}>S P_{i}^{H}$ and $\frac{S P_{2}^{F}}{S P_{2}^{H}}>\frac{S P_{1}^{F}}{S P_{1}^{H}}>1$ for $i=\{1,2\}$. The size of the relative skill premium for the low-educated is 1 both at home and abroad by the initial normalization. In order to judge the relative magnitude of the skill premium in the source and destination countries and its variation across educational attainments, we analyze the actual returns to schooling for the sample of countries described in Section 2. From Table 5 we obtain an opposite pattern: $1>\frac{S P_{1}^{F}}{S P_{1}^{H}}>\frac{S P_{2}^{F}}{S P_{2}^{H}}$. Thus, the model predicts negative selection into initial emigration. 


\section{Result. Predictions of the model.}

Under the assumptions of:

- Free labor mobility

- The experience premium as an exogenous and skill-invariant fraction of wage

- Constant "time-equivalent" immigration costs among educational groups

- The relative returns to schooling abroad and at home smaller than 1 and declining with an increase in the educational attainment,

s.t. $\frac{S P_{2}^{F}}{S P_{2}^{H}}<\frac{S P_{1}^{F}}{S P_{1}^{H}}<1$,

the model predicts negative selection into emigration and equal return migration rates, thus neutral selection into return migration.

The predictions of the model with a multiplicative form of immigration costs with respect to the emigration and return migration patterns are quite unrealistic. As a modification of this model, we relaxed the assumption about the equal distribution of immigration costs across educational groups. In particular, we assumed that the value of parameter $a$ in cost functions (13) and (14) varies with education, such that $a_{0}>a_{1}>a_{2}$, implying a higher value of immigration costs for low-educated agents. However, this modification did not affect the return rates, as parameter a cancels out in equation (38) for return migration rates.

\subsection{Lump-sum Immigration Costs (Section 4.1)}

\section{Individual optimization problem}

Second period: Permanent immigration vs. Return migration

Return migration (conditional on emigration in the previous period) takes place when

$$
W_{i}^{F}-M_{i j} \leq W_{i}^{H} E \Rightarrow M_{i j} \geq W_{i}^{F}-W_{i}^{H} E
$$

Migrants with a value of immigration costs less than $W_{i}^{F}-W_{i}^{H} E$ remain in the foreign country in the second period, thus comprising a category of permanent immigrants. The threshold value of the immigration costs is

$$
\bar{M}_{i}=W_{i}^{F}-W_{i}^{H} E=\mu^{F} S P_{i}^{F}-\mu^{H} S P_{i}^{H} E=\left(\frac{\mu^{F} S P_{i}^{F}}{\mu^{H} S P_{i}^{H}}-E\right) \mu^{H} S P_{i}^{H},
$$

for $i=\{0,1,2\}$. Migrants with educational attainment $i$ and immigration costs smaller than the threshold value $\bar{M}_{i}$ are better off remaining abroad permanently. 
In the case of high immigration costs $M_{j} \geq \bar{M}_{i}$, migrants return to the home country. We assume that in the case of indifference between remaining abroad and returning to the origin country, migrants prefer to return.

First period: Emigration decision

Agent $j$ with educational attainment $i$ and immigration costs smaller than $\bar{M}_{i}=$ $W_{i}^{F}-W_{i}^{H} E$ would emigrate on a permanent basis. Agents with a larger value of immigration costs, higher or equal to the threshold $\bar{M}_{i}$, would consider only temporary immigration. For the latter group, the first period optimization problem looks as follows.

$$
W_{i}^{F}-M_{i j}+W_{i}^{H} E>2 W_{i}^{H} \Rightarrow M_{i j}<W_{i}^{F}-(2-E) W_{i}^{H} .
$$

The threshold value of the immigration costs is:

$\tilde{M}_{i}=W_{i}^{F}-(2-E) W_{i}^{H}=\mu^{F} S P_{i}^{F}-(2-E) \mu^{H} S P_{i}^{H}=\left[\frac{\mu^{F} S P_{i}^{F}}{\mu^{H} S P_{i}^{H}}-(2-E)\right] \mu^{H} S P_{i}^{H}$,

for $i=\{0,1,2\}$. All agents with immigration costs smaller than the threshold value would emigrate, while those agents with a high value of immigration costs would never emigrate. Again, in the case of indifference, agents would remain in the home country. The first-period immigration costs threshold for the permanent immigrants is equal to $W_{i}^{F}-W_{i}^{H}$. This value falls to the interval of the immigration costs for the temporary migrants $(\bar{M}, \tilde{M})$.

\section{Return migration rates}

$$
R R_{i}=\frac{\tilde{N}_{i}-\bar{N}_{i}}{\tilde{N}_{i}}=1-\frac{\bar{N}_{i}}{\tilde{N}_{i}}
$$

\section{Low-educated}

$$
R R_{0}=1-\left[\frac{\frac{\mu^{F}}{\mu^{H}}-E}{\frac{\mu^{F}}{\mu^{H}}-(2-E)}\right]^{\frac{1}{b}}
$$

Middle-educated

$$
R R_{1}=1-\left[\frac{\frac{\mu^{F} S P_{1}^{F}}{\mu^{H} S P_{1}^{H}}-E}{\frac{\mu^{F} S P_{1}^{F}}{\mu^{H} S P_{1}^{H}}-(2-E)}\right]^{\frac{1}{b}}
$$




\section{Highly-educated}

$$
R R_{2}=1-\left[\frac{\frac{\mu^{F} S P_{2}^{F}}{\mu^{H} S P_{2}^{H}}-E}{\frac{\mu^{F} S P_{2}^{F}}{\mu^{H} S P_{2}^{H}}-(2-E)}\right]^{\frac{1}{b}}
$$

Conditions for positive selection into emigration. The model predicts positive selection into emigration when the following conditions are satisfied:

$$
\begin{gathered}
\frac{\tilde{N}_{1}}{\tilde{N}_{0}}>1 \& \frac{\tilde{N}_{2}}{\tilde{N}_{1}}>1 \Rightarrow \\
S P_{1}^{H}>\frac{\frac{\mu^{F}}{\mu^{H}}-(2-E)}{\frac{\mu^{F} S P_{1}^{F}}{\mu^{H} S P_{1}^{H}}-(2-E)}
\end{gathered}
$$

and

$$
\frac{S P_{2}^{H}}{S P_{1}^{H}}>\frac{\frac{\mu^{F} S P_{1}^{F}}{\mu^{H} S P_{1}^{H}}-(2-E)}{\frac{\mu^{F} S P_{2}^{F}}{\mu^{H} S P_{2}^{H}}-(2-E)}
$$

\subsection{Policy Impact (Section 4.2)}

\section{Uncertain emigration opportunities}

Second period. Individual optimization problem: Return migration vs. Permanent immigration. Conditional on having emigrated during the first period of life, a person decides to remain abroad permanently when:

$$
W_{i}^{F}-M_{i j}>E W_{i}^{H} \Rightarrow M_{i j}<W_{i}^{F}-E W_{i}^{H}
$$

The immigration costs threshold: $\bar{M}_{i}=W_{i}^{F}-E W_{i}^{H} \Rightarrow \bar{N}_{i}$.

First period: Emigration decision. Agent $j$ with educational attainment $i$ emigrates when:

$p_{i}\left[\left(W_{i}^{F}-M_{i j}\right)+E W_{i}^{H}\right]+\left(1-p_{i}\right)\left[W_{i}^{H}+W_{i}^{H}\right]>2 W_{i}^{H} \Rightarrow M_{i j}<W_{i}^{F}-(2-E) W_{i}^{H}$

The immigration costs threshold $\tilde{M}_{i}=W_{i}^{F}-(2-E) W_{i}^{H}$ is not affected by the acceptance rate. However, the number of agents who actually emigrate and remain abroad permanently is determined by the immigration policy: $p_{i} \tilde{N}_{i}$ and $p_{i} \bar{N}_{i}$. 
Consequently, the effect of policy on the return migration rates vanishes as

$$
R R_{i}=1-\frac{p_{i} \bar{N}_{i}}{p_{i} \tilde{N}_{i}}=1-\frac{\bar{N}_{i}}{\tilde{N}_{i}}
$$

\section{Uncertain opportunities for permanent immigration}

Second period. Individual optimization problem: Return migration vs. Permanent immigration. Conditional on having emigrated during the first period of life, a person remains abroad permanently when:

$$
q_{i}\left(W_{i}^{F}-M_{i j}\right)+\left(1-q_{i}\right) E W_{i}^{H}>E W_{i}^{H} \Rightarrow W_{i}^{F}-M_{i j}>E W_{i}^{H}
$$

Permanent immigration threshold is $\bar{M}_{i}=W_{i}^{F}-E W_{i}^{H}$. Total number of permanent immigrants in every educational group $i$ is $q_{i} \bar{N}_{i}$.

First period

The emigration decision of temporary emigrants is not affected by the status adjustment rate. Emigration takes place when:

$$
W_{i}^{F}-M_{i j}+E W_{i}^{H}>2 W_{i}^{H} .
$$

The emigration threshold is $\tilde{M}_{i}=W_{i}^{F}-(2-E) W_{i}^{H}$.

The emigration decision of permanent immigrants:

$$
W_{i}^{F}-M_{i j}+q_{i}\left(W_{i}^{F}-M_{i j}\right)+\left(1-q_{i}\right) E W_{i}^{H}>2 W_{i}^{H} .
$$

The immigration costs threshold: $\tilde{M}_{i}^{\prime}=W_{i}^{F}-\frac{2\left(1-q_{i}\right) E}{1+q_{i}} W_{i}^{H}$.

As $\bar{M}_{i}<\tilde{M}_{i}^{\prime}<\tilde{M}_{i}$, the number of emigrants in the first period remains $\tilde{M}_{i}$.

Return migration rates:

$$
R R_{i}=1-\frac{q_{i} \bar{N}_{i}}{\tilde{N}_{i}}=1-\frac{q_{i} \bar{N}_{i}}{\tilde{N}_{i}}=1-\left[\frac{\frac{\mu^{F} S P_{i}^{F}}{\mu^{H} S P_{i}^{H}}-E}{\frac{\mu^{F} S P_{i}^{F}}{\mu^{H} S P_{i}^{H}}-(2-E)}\right]^{\frac{1}{b}} \cdot q_{i} .
$$

The equation for the return migration rates is not defined at $\frac{S P_{i}^{F}}{S P_{i}^{H}}=\frac{2-E}{\mu^{F} / \mu^{H}}$. More- 
over, the return migration rates are non-negative when:

$$
0<\frac{S P_{i}^{F}}{S P_{i}^{H}}<\frac{2-E}{\mu^{F} / \mu^{H}} \& \frac{S P_{i}^{F}}{S P_{i}^{H}} \geq \frac{E}{\mu^{F} / \mu^{H}} \& q_{i} \in[0,1]
$$

\section{First-order partial derivatives}

$$
\begin{gathered}
\frac{\partial R R}{\partial \frac{S P^{F}}{S P^{H}}}=-\frac{2 q \mu^{F}}{b \mu^{H}}\left(1-\frac{2(E-1)}{\frac{\mu^{F} S P_{i}^{F}}{\mu^{H} S P_{i}^{H}}-(2-E)}\right)^{\frac{1-b}{b}} \frac{E-1}{\left(\frac{\mu^{F} S P_{i}^{F}}{\mu^{H} S P_{i}^{H}}-(2-E)\right)^{2}}<0, \\
\frac{\partial R R}{\partial q}=-\left(1-\frac{2(E-1)}{\frac{\mu^{F} S P_{i}^{F}}{\mu^{H} S P_{i}^{H}}-(2-E)}\right)^{\frac{1}{b}}<0
\end{gathered}
$$

Both partial derivatives are continuous and negative for $\frac{S P_{i}^{F}}{S P_{i}^{H}} \geq \frac{E}{\mu^{F} / \mu^{H}} \& q_{i} \in(0,1)$.

Pair-wise comparison of return migration rates

1) $\frac{S P_{0}^{F}}{S P_{0}^{H}}>\frac{S P_{1}^{F}}{S P_{1}^{H}} \& q_{0}<q_{1} \Rightarrow R R_{0}>R R_{1}$

$$
\begin{gathered}
R R_{0}=1-\left[\frac{\frac{\mu^{F}}{\mu^{H}}-E}{\frac{\mu^{F}}{\mu^{H}}-(2-E)}\right]^{\frac{1}{b}} \cdot q_{0} \\
R R_{1}=1-\left[\frac{\frac{\mu^{F} S P_{1}^{F}}{\mu^{H} S P_{1}^{H}}-E}{\frac{\mu^{F} S P_{1}^{F}}{\mu^{H} S P_{1}^{H}}-(2-E)}\right]^{\frac{1}{b}} \cdot q_{1} \cdot \\
\Rightarrow \frac{q_{0}}{q_{1}}<\left(1-\frac{2(E-1)}{\frac{\mu^{F} S P_{1}^{F}}{\mu^{H} S P_{1}^{H}}-(2-E)}\right)^{\frac{1}{b}} \cdot\left(1+\frac{2(E-1)}{\frac{\mu^{F}}{\mu^{H}}-E}\right)^{\frac{1}{b}}<1 \text { if } q_{1} \neq 0 \text { and } \frac{q_{0}}{q_{1}}<1 \\
\Rightarrow \frac{E}{\mu^{F} / \mu^{H}}<\frac{S P_{1}^{F}}{S P_{1}^{H}}<1-\frac{2(E-1)}{\mu^{F} / \mu^{H}}
\end{gathered}
$$

Therefore, return migration rates of the secondary-educated migrants are lower than that of the low-educated migrants when:

$$
\begin{gathered}
\frac{S P_{0}^{F}}{S P_{0}^{H}}=1, \\
\frac{E}{\mu^{F} / \mu^{H}}<\frac{S P_{1}^{F}}{S P_{1}^{H}}<1-\frac{2(E-1)}{\mu^{F} / \mu^{H}}
\end{gathered}
$$




$$
\frac{q_{0}}{q_{1}}<\left(1-\frac{2(E-1)}{\frac{\mu^{F} S P_{1}^{F}}{\mu^{H} S P_{1}^{H}}-(2-E)}\right)^{\frac{1}{b}} \cdot\left(1+\frac{2(E-1)}{\frac{\mu^{F}}{\mu^{H}}-E}\right)^{\frac{1}{b}} \text {, when } q_{1} \neq 0
$$

2) $\frac{S P_{2}^{F}}{S P_{2}^{H}}>\frac{S P_{1}^{F}}{S P_{1}^{H}} \& q_{1}<q_{2} \Rightarrow R R_{2}>R R_{1}$.

$$
\begin{gathered}
R R_{2}=1-\left[\frac{\frac{\mu^{F} S P_{2}^{F}}{\mu^{H} S P_{2}^{H}}-E}{\frac{\mu^{F} S P_{2}^{F}}{\mu^{H} S P_{2}^{H}}-(2-E)}\right]^{\frac{1}{b}} \cdot q_{2} \cdot \\
\Rightarrow \frac{q_{1}}{q_{2}}>\left(1-\frac{2(E-1)}{\frac{\mu^{F} S P_{2}^{F}}{\mu^{H} S P_{2}^{H}}-(2-E)}\right)^{\frac{1}{b}} \cdot\left(1+\frac{2(E-1)}{\frac{\mu^{F} S P_{1}^{F}}{\mu^{H} S P_{1}^{H}}-E}\right)^{\frac{1}{b}} \text { and } \frac{q_{1}}{q_{2}}<1 \text { if } q_{2} \neq 0 . \\
\Rightarrow\left(1-\frac{2(E-1)}{\frac{\mu^{F}}{\mu^{H}} \frac{S P_{2}^{F}}{S P_{2}^{H}}-(2-E)}\right)^{\frac{1}{b}}\left(1+\frac{2(E-1)}{\left.\frac{\mu^{F}}{\mu^{H}} \frac{S P_{1}^{F}}{S P_{1}^{H}}-E\right)}\right)^{\frac{1}{b}}<1 \Rightarrow \frac{S P_{2}^{F}}{S P_{2}^{H}}<\frac{S P_{1}^{F}}{S P_{1}^{H}} \\
\Rightarrow \frac{E}{\mu^{F} / \mu^{H}}<\frac{S P_{2}^{F}}{S P_{2}^{H}}<\frac{S P_{1}^{F}}{S P_{1}^{H}} .
\end{gathered}
$$

Combining conditions from pair-wise comparisons, we obtain a set of restrictions on the values of the relative skill premium and ratios of status adjustment rates under which the current specification of the model predicts U-shaped return migration rates. 


\section{Appendix B: List of Figures}

\section{Re-emigration rates from the US after 5 years of residence}

(2005)

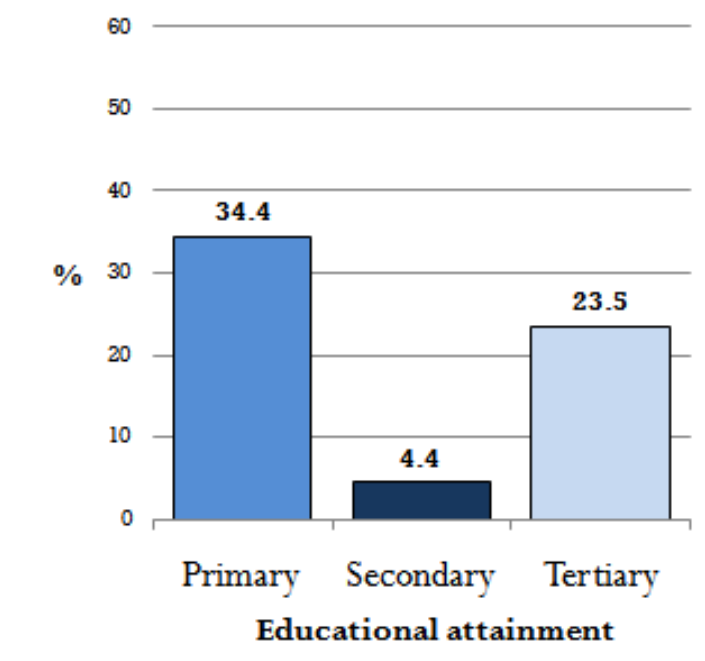

Source: OECD International Migration Outlook(2008).

Figure 1. Aggregate re-emigration rates from the US in 2005.

Notes: Re-emigration rates among males who entered the US in 2000 at the age of 35-64. 
Return from USA

(2000)

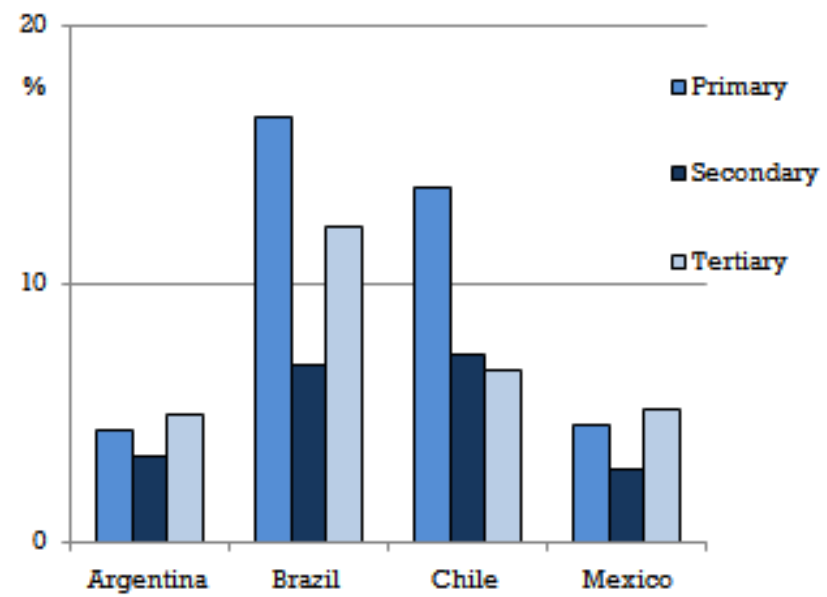

Return from Spain

(2000)

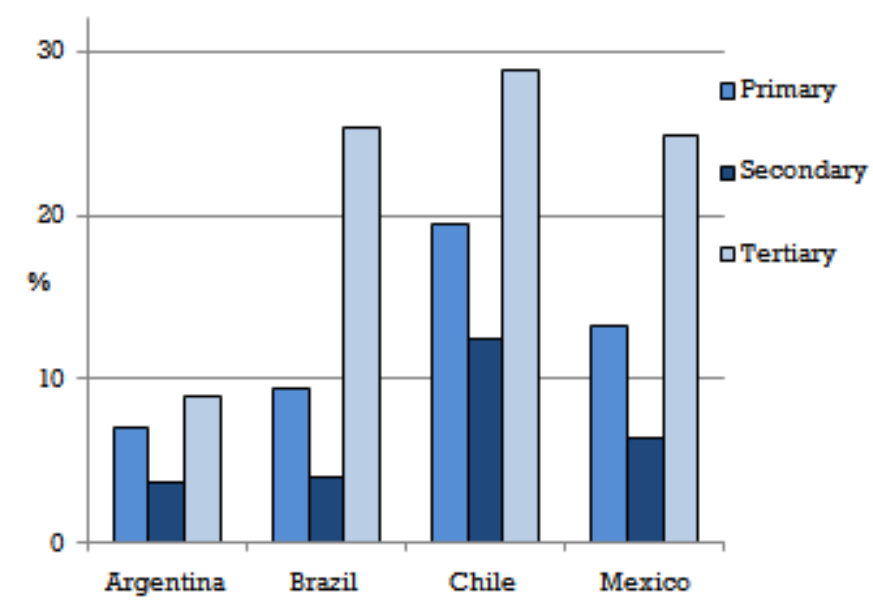

Source: OECD International Migration Outlook (2008)

Figures 2a \& $\mathbf{2 b}$. Return migration rates by educational attainment

Notes: return migration rates for males of age 25-64. Return rates stand for the fraction of return migrants with education $i$ in the total stock of immigrants from the same source country with the same educational attainment $i$, where $i=\{$ low, middle, high $\}$. 


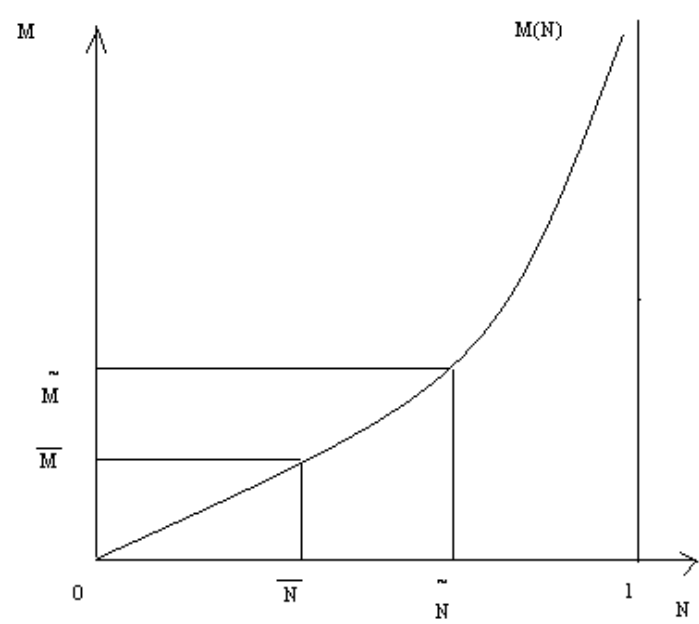

Figure 3. The distribution of the immigration costs $M$ within the educational group i. 


\section{Appendix C: List of Tables}

Table 1. Educational sorting of return migrants

\begin{tabular}{|l|ccc|ccc|}
\hline \multirow{2}{*}{ Source country } & \multicolumn{3}{|c}{ Return rates from the US } & \multicolumn{3}{|c|}{ Return rates from Spain } \\
\cline { 2 - 7 } & Low & Middle & High & Low & Middle & High \\
\hline Argentina & 4.2 & 3.1 & 4.4 & 6.5 & 3.1 & 9.6 \\
Brazil & 16 & 6 & 11.3 & 9.3 & 3.7 & 25.2 \\
Chile & 13.6 & 6.4 & 5.7 & 19.6 & 13.2 & 29.8 \\
Mexico & 4.3 & 1.6 & 5 & 12.9 & 6.3 & 24.8 \\
\hline Jamaica* & 13.4 & 4.8 & 13 & N/A & N/A & N/A \\
Colombia* & 1.3 & 0.92 & 0.94 & N/A & N/A & N/A \\
Ghana* & 1.2 & 0.6 & 0.9 & N/A & N/A & N/A \\
Macedonia * & 1 & 0.7 & 3 & N/A & N/A & N/A \\
Vietnam * & 0.95 & 0.84 & 1.87 & N/A & N/A & N/A \\
\hline
\end{tabular}

Sources and Notes:

Return migration rates: OECD IMO 2008. Return rate is calculated as a fraction of the returned population with educational attainment $i$ in the total stock of emigrants from the same source country with the same educational level $i$, where $i=\{$ low, middle, high $\}$.

*For the countries in the lower part of the table we use return ratios instead of return rates. The return ratio is calculated as a fraction of two shares - share of returnees with educational attainment $i$ in the total number of return migrants in the numerator and share of immigrants with educational attainment $i$ in the total number of immigrants with the same educational attainment i. We consider emigration and return migration from all destinations, including the US. The return ratios represent the calculations of the authors using data from the DotM Project. 
Table 2. Labor supply and returns to schooling, 2000

\begin{tabular}{|c|c|c|c|c|c|c|c|}
\hline \multirow[b]{2}{*}{ Countries } & \multicolumn{3}{|c|}{ Relative skills supply } & \multicolumn{2}{|c|}{$\begin{array}{l}\text { Returns to } \\
\text { schooling }\end{array}$} & \multicolumn{2}{|c|}{$\begin{array}{l}\text { Relative returns } \\
\text { (USA/Home) }\end{array}$} \\
\hline & $\mathbf{L}_{0} / \mathbf{L}_{1}$ & $\mathbf{L}_{1} / \mathbf{L}_{2}$ & $\mathbf{L}_{0} / \mathbf{L}_{2}$ & $\begin{array}{c}\mathrm{SP}_{1} \\
\left(\mathrm{~W}_{1} / \mathrm{W}_{0}\right)\end{array}$ & $\begin{array}{r}\mathbf{S P}_{2} / \mathrm{SP}_{1} \\
\left(\mathrm{~W}_{2} / \mathrm{W}_{1}\right)\end{array}$ & $\mathbf{S P}^{\mathrm{F}}{ }_{1} / \mathbf{S P}_{1}^{\mathrm{H}}$ & $\mathbf{S P}_{2}{ }_{2} / \mathbf{S P}_{2}$ \\
\hline \multicolumn{8}{|l|}{ Source countries } \\
\hline Argentina & 2.2 & 6.3 & 13.9 & 0.448 & 0.449 & 0.67 & 0.89 \\
\hline Brazil & 4.95 & 3.0 & 14.9 & 0.827 & 0.826 & 0.36 & 0.26 \\
\hline Chile & 1.7 & 3.7 & 5.6 & 0.619 & 0.897 & 0.48 & 0.32 \\
\hline Mexico & 4.97 & 1.5 & 7.2 & 0.578 & 0.468 & 0.52 & 0.67 \\
\hline Vietnam & 11 & 5.47 & 60.2 & 0.52 & 0.68 & 0.58 & 0.51 \\
\hline Macedonia & 1.76 & 2.3 & 4.0 & 0.497 & 0.701 & 0.60 & 0.52 \\
\hline Colombia & 3.9 & 1.97 & 7.8 & 0.458 & 0.691 & 0.66 & 0.57 \\
\hline Jamaica & 2.2 & 3.5 & 7.8 & na & na & na & na \\
\hline Fiji & 0.8 & 7.7 & 6.5 & na & na & na & na \\
\hline Ghana & 6.6 & 26.2 & 70 & na & na & na & na \\
\hline \multicolumn{8}{|c|}{ Destination countries } \\
\hline USA & 0.3 & 1.4 & 0.5 & 0.3 & 0.6 & & \\
\hline Spain & 3.5 & 0.7 & 0.3 & 0.33 & 0.42 & & \\
\hline
\end{tabular}

Sources: Docquier \& Marfouk (2006); Goldin \& Katz ( 2007); Manacorda, Sanchez-Paramo \& Schady (2005).

Notes: $\mathrm{L}_{0}, \mathrm{~L}_{1}$, and $\mathrm{L}_{2}$ stand for the shares of the resident population of age 25-64 with primary, secondary and tertiary education respectively. Returns to schooling represent log wage differentials between two educational attainments. 
Table 3. Educational structure of the population and emigration rates, 2000

\begin{tabular}{|c|c|c|c|c|c|c|c|c|c|c|c|c|}
\hline \multirow[b]{2}{*}{ Country } & \multicolumn{3}{|c|}{ Resident population } & \multicolumn{3}{|c|}{ Emigration rates (OECD), \% } & \multicolumn{3}{|c|}{ Emigration rates USA, \% } & \multicolumn{3}{|c|}{ Emigration rates Spain, \% } \\
\hline & $\mathrm{L}$ & M & $\mathrm{H}$ & $\mathrm{L}$ & M & $\mathrm{H}$ & $\mathrm{L}$ & M & $\mathrm{H}$ & $\mathrm{L}$ & M & $\mathrm{H}$ \\
\hline \multicolumn{13}{|c|}{ Source countries } \\
\hline Argentina & 65.7 & 29.6 & 4.7 & 0.49 & 1.58 & 2.78 & 0.20 & 0.44 & 1.49 & 0.13 & 0.81 & 0.56 \\
\hline Brazil & 78.7 & 15.9 & 5.3 & 0.17 & 1.14 & 2.05 & 0.05 & 0.33 & 1.11 & 0.01 & 0.11 & 0.07 \\
\hline Chile & 53.3 & 37.2 & 9.5 & 0.93 & 1.63 & 6.02 & 0.30 & 0.48 & 2.59 & 0.04 & 0.253 & 0.249 \\
\hline Mexico & 74 & 14.9 & 10.2 & 13.9 & 7.02 & 15.5 & 13.9 & 6.9 & 15.0 & 0.01 & 0.04 & 0.10 \\
\hline Colombia & 72.1 & 18.5 & 9.4 & 1.1 & 4.1 & 10.4 & 0.81 & 2.31 & 8.21 & 0.19 & 1.47 & 0.79 \\
\hline Jamaica & 63.1 & 28.7 & 8.1 & 23.5 & 26 & 84.7 & 0.13 & 0.19 & 0.59 & na & na & na \\
\hline Macedonia & 54.9 & 31.2 & 13.8 & 16.5 & 10.9 & 29.4 & 0.08 & 0.49 & 8.80 & 1.51 & 0.63 & 0.20 \\
\hline Vietnam & 90.3 & 8.2 & 1.5 & 1.67 & 5.09 & 26.9 & 1.00 & 3.16 & 18.5 & 0.01 & 0.09 & 0.04 \\
\hline Fiji & 42.6 & 50.8 & 6.6 & 11.7 & 15.07 & 62.8 & 3.21 & 4.32 & 11.7 & 2.66 & 4.83 & 26.92 \\
\hline Ghana & 86.4 & 13.1 & 0.5 & 0.89 & 2.2 & 44.7 & 0.12 & 0.64 & 21.9 & 0.20 & 0.90 & 11.66 \\
\hline \multicolumn{13}{|c|}{ Destination countries } \\
\hline USA & 15.9 & 53.5 & 30.6 & 1.3 & 0.2 & 0.5 & - & - & - & 0.013 & 0.006 & 0.008 \\
\hline Spain & 63.6 & 24.3 & 12.1 & 2.2 & 2.1 & 4.2 & 0.09 & 0.28 & 1.12 & - & - & - \\
\hline
\end{tabular}

Sources: Barro \& Lee, 2010; Docquier \& Marfouk, 2006; Education at a Glance, 2001, 2002.

Notes: Emigration rates stand for the fraction of emigrants from a particular source country with educational attainment $i$ in the total stock of the resident population of the source country with the same educational attainment $i$, where $i=\{$ low, middle, high $\}$. Unless the destination is specified (USA or Spain), emigrants departing to all destinations are considered. 
Table 4. US immigration policy

\begin{tabular}{|c|c|c|c|}
\hline \multirow{2}{*}{$\begin{array}{l}\text { Skill } \\
\text { group }\end{array}$} & Admission categories & Status adjustment & Return migration \\
\hline & \multicolumn{3}{|c|}{ Temporary non-immigrant admissions } \\
\hline $\begin{array}{l}\text { Low- } \\
\text { educated }\end{array}$ & $\begin{array}{l}\text { 1) H-2 type: Temporary and seasonal } \\
\text { workers } \\
\qquad \quad \text { H-2A: agricultural } \\
\text { Annual quota: } \mathbf{6 6 , 0 0 0} \text { for } \mathrm{H}-2 \mathrm{~B} \\
\text { Unlimited admission under H-2A } \\
\text { Maximum duration: } 1 \text { year } \\
\text { Prolongation: up to } 3 \text { years } \\
\text { Educational requirement: None } \\
\text { Employer requirements: US } \\
\text { employer } \\
\text { Change of employer: not allowed }\end{array}$ & $\begin{array}{l}\text { No direct status adjustment } \\
\text { option } \\
\text { Permanent residence permit: } \\
\text { - Employment sponsorship } \\
\text { Do not qualify for any of } 4 \\
\text { preference categories. } \\
\text { - Family sponsorship } \\
\text { (Relative of US citizen or legal } \\
\text { immigrant) }\end{array}$ & $\begin{array}{l}\text {-Completion of the } \\
\text { contract (seasonal or } \\
\text { temporary work); } \\
\text {-Loss of the employment } \\
\text { contract; } \\
\text {-Exceeding maximum } \\
\text { duration of stay ( } 3 \text { years) }\end{array}$ \\
\hline $\begin{array}{l}\text { Middle- } \\
\text { educated }\end{array}$ & $\begin{array}{l}\text { 1) H-2 type: Temporary and seasonal } \\
\text { workers } \\
\text { (Same as for low-educated) } \\
\text { 2) Diversification program (Green } \\
\text { Card lottery) } \\
\text { Annual quota: } \mathbf{5 5 , 0 0 0} \\
\text { Status: legal immigrant } \\
\text { Duration: } 10 \text { years } \\
\text { Educational requirement: high } \\
\text { school degree and two years of } \\
\text { experience } \\
\text { Employer requirement: not needed }\end{array}$ & $\begin{array}{l}\text { Specific for middle-skilled } \\
\text { Apply for the naturalization } \\
\text { after } 5 \text { years of uninterrupted } \\
\text { stay in the US } \\
\text { Restrictions: restricted list of } \\
\text { source countries }\end{array}$ & $\begin{array}{l}\text {-Loss of the immigrant } \\
\text { status if a person remains } \\
\text { outside USA longer than } 2 \\
\text { months per year. }\end{array}$ \\
\hline $\begin{array}{l}\text { Highly- } \\
\text { educated }\end{array}$ & $\begin{array}{l}\text { 1) H-2 type } \\
\text { Same as in two previous skill groups } \\
\text { 2) H-1B type } \\
\text { Annual quota: } 85,000 \\
\text { Maximum duration: } 3 \text { years } \\
\text { Prolongation: up to } 3 \text { years } \\
\text { Educational requirement: B.A. } \\
\text { degree or higher } \\
\text { Origin: restricted list of countries } \\
\text { 3) O type } \\
\text { People with extraordinary abilities } \\
\text { 4) Diversification program }\end{array}$ & $\begin{array}{l}\text { All limitations of } \mathbf{H}-2 \text { admission } \\
\text { as in other skill groups } \\
\text { Direct status adjustment } \\
\text { under } \mathbf{H}-1 \mathrm{~B} \text { admission } \\
\text { Restrictions: } 4 \text { preference } \\
\text { categories }\end{array}$ & $\begin{array}{l}\text { Same reasons as for low } \\
\text { educated under H-2 } \\
\text { admissions. } \\
\text { Long waiting period for } \\
\text { status adjustment for } \\
\text { immigrants from particular } \\
\text { preference categories (E3) } \\
\text { and from the } \\
\text { overrepresented source } \\
\text { countries. }\end{array}$ \\
\hline
\end{tabular}

Source: Papademetrious, Meissner \& Rosenblum (2009). 


\section{Working Paper Series}

ISSN 1211-3298

Registration No. (Ministry of Culture): E 19443

Individual researchers, as well as the on-line and printed versions of the CERGE-EI Working Papers (including their dissemination) were supported from the European Structural Fund (within the Operational Programme Prague Adaptability), the budget of the City of Prague, the Czech Republic's state budget and the following institutional grants:

- Center of Advanced Political Economy Research [Centrum pro pokročilá politickoekonomická studia], No. LC542, (2005-2011);

- Economic Aspects of EU and EMU Entry [Ekonomické aspekty vstupu do Evropské unie a Evropské měnové unie], No. AVOZ70850503, (2005-2011);

- Economic Impact of European Integration on the Czech Republic [Ekonomické dopady evropské integrace na ČR], No. MSM0021620846, (2005-2011);

Specific research support and/or other grants the researchers/publications benefited from are acknowledged at the beginning of the Paper.

(c) Renata Ivanova and Byeongju Jeong, 2011

All rights reserved. No part of this publication may be reproduced, stored in a retrieval system or transmitted in any form or by any means, electronic, mechanical or photocopying, recording, or otherwise without the prior permission of the publisher.

Published by

Charles University in Prague, Center for Economic Research and Graduate Education (CERGE) and

Economics Institute ASCR, v. v. i. (EI)

CERGE-El, Politických vězňů 7, 11121 Prague 1, tel.: +420 224005 153, Czech Republic.

Printed by CERGE-EI, Prague

Subscription: CERGE-EI homepage: http://www.cerge-ei.cz

Phone: + 420224005153

Email: office@cerge-ei.cz

Web: http://www.cerge-ei.cz

Editor: Michal Kejak

Editorial board: Jan Kmenta, Randall Filer, Petr Zemčík

The paper is available online at http://www.cerge-ei.cz/publications/working_papers/.

ISBN 978-80-7343-252-2 (Univerzita Karlova. Centrum pro ekonomický výzkum a doktorské studium)

ISBN 978-80-7344-244-6 (Národohospodářský ústav AV ČR, v. v. i.) 
CERGE-EI

P.O.BOX 882

Politických vězňů 7

11121 Praha 1

Czech Republic http://www.cerge-ei.cz 